\title{
Cuestiones controvertidas acerca de los judíos en la Historia Antigua peninsular *
}

\author{
J. J. Sayas Abengochea **
}

Michael Koch al comiezo de su Zur frühen jüdischen Diaspora auf lberischen Halbinsel, publicado en el $1977^{1}$ recordaba como un hecho digno de señalar que cuando J. Hashagen ${ }^{2}$ dio a la luz en el 1940 su pequeño y sustancioso trabajo sobre la diáspora israelita anterior al exilio, apenas tuvo a disposición una media docena de obras que guardasen relación con el tema. Con posterioridad, el panorama ha cambiado sustancialmente. Puede decirse que el número de libros y artículos relacionados con los judíos de la Antigüedad se ha triplicado y no ha cesado de aumentar de año en año. En muchos de estos trabajos se han ensayado, y de forma altamente satisfactoria, nuevas vías de análisis, al mismo tiempo que se incorporaban los perfeccionamientos metodológicos conseguidos en otros campos de la investigación histórica. En esta voluminosa producción científica, vivificada con la aportación de sólidos avances metodológicos en los terrenos histórico y linguístico, y alimentada por nuevos hallazgos arqueológicos, se estudiaba a los judíos en lo que podriamos llamar propiamente la intrahistoria del pueblo judío, cuanto en sus conexiones con otros pueblos del entorno, sobre todo por lo que respecta a las mutuas influencias y confrontaciones que sostuvieron con la cultura pagana y con la cristiana ${ }^{3}$.

* Ponencia presentada en el Encuentro Internacional de Historiadores «En torno a Sefarad». Toledo, diciembre de 1991.

$\star \star$ UNED.

$\mathrm{KoCH}$, M., "Zur frühen jüdischen Diaspora auf der iberischen Halbinsel», en Homenaje a Garcia y Bellido, III. Madrid 1977, págs. 225-254, aqui pág. 225.

2 Hastiagen, J., “Vorexilische Diaspora», ThQ, n. ${ }^{\circ} 121,1940$, págs. 211-216.

3 La producción científica que en las últimas décadas ha abordado diversas cuestiones relacionadas con los judios, es voluminosa e importante. Citaremos tan sólo algunos títulos, que centran la investigación, por un lado, sobre la situación de los judíos en los distintos pe- 
Es evidente que en todo este tiempo el conocimiento alcanzado sobre la progresiva conformación del pensamiento judío, por una parte, y sobre los tempranos asentamientos israelitas llevados a cabo fuera de las tierras palestinas, por otro, ha aumentado cualitativa y cuantitativamente. En lo que se refiere a asentamientos orientales y extrapeninsulares conocidos con relativa suficiencia, eso es desde luego cierto en términos generales. Por el contrario, el tema del conocimiento de los más antiguos judíos peninsulares nos remite a una situación bastante diferente, si la comparamos con la que corresponde a los asentamientos judíos efectuados en otros lugares. No se trata, en esta ocasión de la queja, reiteradamente emitida, acerca de la desprotección científica, del lamentable estado de la investigación española o de la desidia en las indagaciones sobre temas españoles en general y sobre aquellos que pudieron resultar conflictivos en particular. No es eso. Un cotejo superficial en cualquier obra que recoja un breve balance de la investigación sobre judíos de la Antigüedad, pondrá de manifiesto la sustantiva cantidad de obras importantes relacionadas con el tema, que está a disposición de cualquier investigador ${ }^{4}$. La cues-

ríodos históricos y, por otro, en algunos aspectos concretos. Para los judíos de la época aqueménida hay que destacar la obra de ACKROYD, P. R., Israel under Babylon and Persia. Londres 1970; SMITH, M., Palestinian Parties and Politics which Shaped the Old Testament. Nueva YorkLondres 1971. Para el período helenístico-romano, durante el cual se produce el afianzamiento judio, se puede destacar la obra de Schalit, A. (ed.), World History of the Jewish People //6: The Hellenistic Age. Jerusalén 1972 y la de HENGEL, M., Juden, Griechen und Barbaren. Stuttgart 1976. Para una visión general de la historia de los judíos durante la época romana, ver el trabajo de Smallwood, E. M., "The Jews under Roman Rule. From Pompey to Diocletian", Studies in Judaism in Late Antiquity. Leiden 1976 y la visión general que proporciona Grant, M., The Jews in the Roman World. Londres 1973. Esenciales son los diversos trabajos recogidos en SAFRAI, S. y Stern, M. (eds.), The Jewish People in the First Century. Historical Geography, Political History, Social, Cultural and Religious Life and Institutions I-II. Compendia Rerum ludaicarum ad Novum Testamentum, Sección I. Assen 1974-1976 y la visión que proporciona STEMBerger, G., Das klassische Judentum. Kultur und Geschichte der rabbinischeen Zeit. Múnich 1979. Resulta muy atractivo el estudio breve y general que sobre los diversos periodos de la Antigüedad ha realizado MAIER, J., Grundzüge der Geschichte des Judentums im Altertum. Darmstadt 1981.

Para las relaciones y contrastes de los judíos con paganos cristianos, Conzelmann, H., Heiden, Juden, Christen. Auseinandersetzungen in der Literatur der hellenistisch-römischen Zeit. Tübingen 1981. Para una visión judía del dominio romano, ver Stemberger, G., Die römische Herrschaft im Urteil der Juden. Darmstadt 1983.

Por lo que se refiere a las raíces paganas del antisemitismo ver Sevenster, N., The Roots of Pagan Anti-Semitism in the Ancient World, Suppl. al NT 41. Leiden 1975.

Las fuentes literarias griegas y latinas se encuentran recogidas por STERN, M., Greek and Latin Authors on Jews and Judaism I-II. Jerusalén 1974-1980. El compendio hecho por NEHERBenNHEIM, R., Le judaisme dans le monde romain. Textes latins commentés. París 1959, recoge las referencias literarias latinas más importantes referentes a los judios.

4 La obra de AMAdOR De los Rios, J., Historia social de los judíos de España y Portugal. Madrid 1876, reimpr. 1960, aunque está superada, contiene muchos elementos que resultan útiles todavía. Son interesantes los trabajos generales de VALLE, C. del, El mundo judío. Historia. Religión. Cultura, UNED, “Aula Abierta». Madrid 1976, pág. 345 y ss., con valoración de los 
tión es que, pese a la cantidad y validez de esta producción investigadora, el problema de la discutible y temprana presencia de israelitas en tierras de la Península Ibérica no ha cambiado sustancialmente con relación a los planteamientos ya sostenidos y esgrimidos en décadas anteriores.

Por desgracia, todavía tiene vigencia la cuestión icuándo llegaron los judíos a España?, con la que Beinart, en el 1962, encabezaba uno de sus trabajos ${ }^{5}$. En este sentido, y aunque quizá convendría haber tenido presentes las aportaciones y matizaciones que las recientes investigaciones habian ofrecido al respecto, creo que no se encontrarían muy alejadas de constituir una respuesta adecuada a la situación real, las palabras que en su día emitió L. Suárez y que podemos considerar como respuesta a la cuestión de Beinart: "Las más antiguas menciones de judíos en la Península nos conducen a la época del Imperio Romano. Todo lo demás es mitología ridícula" ${ }^{6}$. Es una postura rigurosa, aunque desde el punto de vista histórico correcta. Está claro que la misión del historiador consiste

trabajos más significativos; de LACALLE SALINAS, J. M., Los judios españoles. Barcelona 1961 y el de Torroba Bernaldo de Quirós, F., Los judios españoles. Madrid 1967.

GaRcía Iglesias, L., Los judios de la España antigua. Madrid 1978, ha abordado con detenimiento el estudio de los judios de la Hispania antigua en una obra en la que recoge el estado de la cuestión y registra la mención a los trabajos científicos más significativos. A este especialista se debe, además, una serie de trabajos sobre los antiguos judíos de la Península lbérica: "Los judíos en la España romana», $H A, n{ }^{\circ} 3,1973$, págs. 331-366; "Profesiones y economia familiar de los judios españoles en la antigüedad: aproximación a un problema", Revista internacional de Sociología, $.^{\circ \mathrm{s}} 13-14,1975$, págs. 165-183; "Los cánones del concilio de Elbira y los judíos", El Olivo, n. ${ }^{\circ 8} 3-4,1977$, págs. 61-70.

La temprana presencia de judíos en la Península lbérica se encuentra tratada por BLÁzouez, J. M., «Relaciones entre Hispania y los semitas (sirios, fenicios, chipriotas, cartaginenses y judíos) en la Antigüedad", en Beiträge zur alten Geschichte und deren Nachleben. Festschrift für Franz Altheim I. Berlín 1969, págs. 42-75, ahora en BLÁzQUEZ, J. M., Economía de la Hispania romana. Bilbao 1978, págs. 619-646, mientras que BowERS, W. P., "Jewish communities in Spain in the Time of Paul the Apostle", The Journal of Theological Studies, n. XXVI, 1975, págs. 395 402 plantea la cuestión de la presencia de comunidades judías en Hispania en época de San Pablo. Hay que destacar también, por diversos motivos, la obra de BAEA, Y., A History of the Jews in Christian Spain I. Filadelfia 1961, trad. de L. Schofman.

Por lo que hace referencia a la documentación epigráfica de época romana y visigoda, debe registrarse los trabajos de CANTERA, F. y MILLÁS, J. M., Las inscripciones hebraicas de España. Madrid 1956 y el importante artículo de CANTERA, F., "España medieval: Arqueología», en The Sephardi Heritage, vol. I. Londres 1971. Para la política judia seguida por los visigodos y las disposiciones legales emitidas por los visigodos, ver los trabajos de KATZ, S., The Jews in the Visigothic and Frankish Kingdoms of Spain and Gaul. Cambridge-Mass. 1939; BACHRACH, B. S., "A Reassessment of Visigothic Jewish Policy", The American Historical Review, 78, 1973, págs. 11-34; LACAVE, J. L., "La legislación antijudía de los Visigodos", en Simposio Toledo Judaico. Toledo 1973, págs. 31-42.

s BeInART, J., “¿Cuándo llegaron los judios a España?», n. ${ }^{\circ} 3$ de Estudios del Instituto Central de Relaciones Culturales Israel-Iberoamérica, España y Portugal, 1962. Ver también BEINART, H., Los comienzos del judaísmo español. Buenos Aires 1973.

6 SuÁrez Fernández, L., Judíos españoles en la Edad Media. Madrid 1980. 
en establecer adecuadamente el proceso intelectual, mediante el cual se pueda llegar a conocer la realidad histórica a partir de las huellas de diversa índole que los hechos históricos dejan en las fuentes. El conocimiento histórico se basa en pruebas, y, si éstas faltan, podrá haber poemas épicos, leyendas, tradiciones, etc., pero no Historia; por otra parte, si las pruebas son insuficientes, no se puede llegar a conclusiones históricamente seguras. Ahora bien: es en este último terreno de incertidumbre donde se mueve necesariamente el historiador que pretenda estudiar la temprana presencia judía en España. $Y$ ello no depende, como ha especificado A. Momigliano ${ }^{7}$, de que los problemas, que surgen al tratar de verificar la verdad de la información y de comprender los textos, sean diferentes en la historia judía que en la griega o en la romana.

Para fechas tempranas, resulta altamente difícil el poder disponer de testimonios literarios o epigráficos inequívocamente referidos a judios en España, o contar, por otra parte, con objetos arqueológicos de innegable raigambre israelita ${ }^{8}$. No hay epígrafes, y los datos referentes a España que contienen algunas fuentes literarias requieren el oportuno análisis cautelar. Esta deficiencia de la documentación crea manifiestas dificultades para que el historiador pueda conocer plenamente la verdad del pasado. Por otra parte, los objetos arqueológicos que se tienen a disposición nos remiten al mundo colonial fenicio y a un ámbito colonial sirofenicio, en el que han fermentado y se han acrisolado influencias culturales diversas. Es cierto que el peso de la religión israelita se dejó sentir en el arte; ello se percibe en la escasa representación figurativa de la escultura y la pintura. Es en las obras arquitectónicas y en los objetos correspondientes a las artes menores donde se encuentran las características más significativas. Pero estas manifestaciones de la cultura material son semejantes en toda esa zona del Mediterráneo oriental ${ }^{9}$. La moderna Arqueología ${ }^{10}$,

7 Ver la opinión al respecto de Momigliano, A., "Studi biblici e studi classici», en La storiografia greca. Turín 1982.

8 Reifenderg, A., Ancient Hebrew Arts. Nueva York 1950, ofrece una visión general de to que denomina "arte hebreo". Lo cierto es que si por "arte hebreo" entendemos el estudio de todas aquellas obras y monumentos que se encuentran en tierras hebreas o proceden de las mismas, entonces no hay duda que podemos hablar de arte hebreo. Pero si, por el contrario, la indagación metodológica tiene por cometido determinar la esencia interna de ese "arte hebreo" y especificar sus características peculiares, entonces ya no se puede hablar en sentido estricto de la existencia de arte hebreo.

9 Es evidente que el arte fenicio en su conjunto ofrece un panorama bastante fragmentario. Por otra parte, se trata de un arte cerrado en sí mismo, sino que se encontraba abierto a influencias foráneas. Se trata de un arte que, dentro de su originalidad, va adaptándose a las nuevas pautas, al ritmo que le imponen las exigencias mercantiles de la sociedad fenicia, de la que son exponentes las manifestaciones culturales. Para las raices del arte fenicio, ver Frank. FORT, H., Arte y arquitectura del Oriente Antiguo, vers. cast. Madrid 1982, págs. 251-292; Dus. 
a través de diversos procedimientos, ha podido deducir que en los magníficos edificios construidos por Salomón, incluso el Templo de Jerusalén, confluyen las mismas y diversas influencias arquitectónicas y artísticas que se perciben en construcciones fenicias ${ }^{11}$. Por eso, aun en el caso hipo-

SAUD, R., L'art phénicien du ll millénaire. París 1949; Bossert, H. T., Altsyrien. Tübingen 1951. Para épocas más avanzadas, el arte fenicio asume influencias diversas, como dice Moscati, $S$., L'Ori entavant les Grecs. Les civilisations de la Méditerrée antique, vers. franc. París 1963, págs. 251-255, aquí pág. 255. Ver también la breve pero enjundiosa sintesis que ofrece este autor en Las antiguas civilizaciones semiticas, vers. cast. Barcelona 1960, págs. 133-135.

Para las diversas cuestiones relacionadas con los marfiles fenicios, la dispersión geográfica de los mismos y las influencias que confluyen en ellos, ver DeCAMPS DE MERTzENFELD, C., Inventaire commenté des ivoires phéniciens et apparentés découverts dans le proche-Orient. París 1954; KanTOR, H. J., "Syro-Palestinian Ivories", Journal of Near Eastern Studies, n. ${ }^{\circ} 15,1956$, págs. 153-174; BARNETT, R. D., A Catalogue of the Nimrud Ivories with other Examples of Ancient Near Eastern Ivories in the British Museum. Londres 1957; Crowfoot, J. W.; Crowfoot, G. M. y SUKENIK, E., Early ivories from Samaria. Londres 1938.

to Salomón adornó a la monarquía de aquellos signos exteriores que pueden considerarse como indicativos de un gran poder: un gran harém, palacio suntuoso, fortalezas e interés por las artes, ver Lods, A., Israël. Des origines au milieu du VIII sièc/e avant notre ére. Paris 1969, págs. 366-372. Las representaciones figurativas no abundan en las manifestaciones escultóricas y pictóricas, en razón a la ascendencia que en este terreno tiene el elemento religioso. Eso hace que sea en la arquitectura en el que se han realizado las producciones más significativas. Se tienen documentados restos de estos monumentos y se dispone de información acerca de ciudadelas fortificadas, de palacios, de templos, de instalaciones portuarias, de sistemas hidráulicos, grandes establos, etc., que se cree pertenecen a la época de Salomón, ver al respecto KENYON, Archeology in the Holy Land. Nueva York 1950. Entre estos hallazgos se encuentran los establos de la ciudad de Meggido, que se suponen que corresponden a la época de Salomón, ver PritChARD, J. B., La Arqueología y el Antiguo Testamento, vers. cast. Buenos Aires 1962, págs. 48-52; Connfeld, G., Arqueología de la Biblia. De Abraham a Jesús, vers. cas. Buenos Aires 1980, págs. 126-138.

1 Se cuenta con restos de ciudadelas y palacios. Los muros y las estructuras arquitectónicas de estos edificios siguen modelos y tradiciones cananeas, como ha puesto de manifiesto Albright, W. F., The Archaeology of Palestine. Londres 1949 y PARRot, A., Samarie, capitales du royaume d'Israël. Neuchàtel 1955. No se dispone, sin embargo, de monumentos religiosos. Por lo que hace a las referencias literarias alusivas a la descripción del Templo de Jerusalén, éstas permiten reconstruir el mismo con relativa exactitud, ver al respecto el trabajo de PARROT, A., Le Temple de Jérusalem. Neuchätel 1954; Connfelo, G., "Arqueología de la Biblia...", op. cit., págs. 126-128. Las inquietudes artísticas se han plasmado también en los relieves de los sellos y de las placas de marfil, ver Reifenberg, A., Ancient Hebrew seals. Londres 1950. Por lo que hace referencia a los marfiles, ver Crowfoot, J. W.; Crowfoot, G. M. y SUKEnIK, E. L., Early ivories from Samaria. Londres 1938.

Con relación a la pregunta que pudiera plantearse respecto a la originalidad específica de la estructura arquitectónica del Templo de Jerusalén, hay que tener presente que, en ausencia de datos materiales, los indicios literarios permiten establecer paralelos con restos de otros santuarios como los de Shiloh y de Tell Ta'inat. $Y$ las semejanzas entre dichos santuarios son muy próximas; no se puede hablar, por tanto, de una originalidad hebrea. Lo mismo ocurre respecto de los elementos ornamentales. Éstos se encuentran en estrecha relación con los trabajos realizados por los artesanos fenicios, que Salomón había solicitado para trabajar en las obras por él emprendidas, ver al respecto la obra de MoscatI, S., "L'Orient avant les Grecs...", op. cit., pág. 302; ChOURAQUI, A., La vie quotidienne des Hébreux au temps de la Bible. Rois et Prophètes. París 1971, págs. 119-120; CoRNFELD, G., Arqueología..., op. cit., págs. 
tético ${ }^{12}$ de que algún objeto de los registrados en España durante los momentos de la colonización fenicia hubiese sido traido por judíos, resultaría harto difícil detectar en el mismo algún elemento inequívocamente hebreo. Por tanto, en términos de estricta puridad metodológica, hay que decir que no se dispone de datos históricos directos e inequívocos, ni tampoco de hallazgos arqueológicos significativos, con cuya ayuda pudieran el historiador y el arqueólogo, en sus respectivas actividades investigadoras, verificar, con toda la carga semántica que lleva este término, una posible y temprana presencia judía en España. Pero la falta de elementos arqueológicos específicos y la inexistencia de datos históricos de referencia expresa a judíos no invalida, como si se tratara de una exclusión mecánica, relegada al terreno de la ficción, la sólida sugerencia, deducida de indicios indirectos, de una temprana presencia judía en España.

¿De qué tipo son estos indicios? Algunos de ellos, de manifiesta endeblez, los proporcionan una serie de relatos fantásticos y leyendas. Durante la Edad Media en ambientes judíos españoles fueron adquiriendo forma una serie de relatos legendarios con la pretendida intencionalidad de testimoniar la existencia de una supuesta presencia judía en la Península en época de Salomón, por un lado, y como una de las consecuencias de la toma de Jerusalén por Nabucodonosor en el año 587 a.C., por otro. Se trata, por tanto, de un material informativo peculiar, que no nace en época medieval ex novo, sino que se conforma y amalgama con leyendas y relatos fantásticos anteriores ${ }^{13}$. En la singladura cultural de muchos pueblos existe un conjunto de tradiciones y leyendas que constituye un rico acervo cultural que singulariza y caracteriza a dichos pueblos. Por otra parte, no son pocos los historiadores del arte que perciben, en la

126-128 reiteran esas influencias del arte fenicio, que, a su vez, tampoco tiene características especificas, sino que asume y participa de las caracteristicas, que se dan en las obras artísticas de las regiones próximas. $Y$ estos paralelos e influencias captadas en objetos procedentes de otros lugares se perciben también en sellos encontrados en tierras hebreas que presentan influencias egipcias y sirias, y en las placas de marfil, que a su vez ofrecen influencias fenicias y sirias. Ver al respecto, Moscatı, S., "L'Orient avant les Grecs...", op. cit., págs. 302-304; idem, "Las antiguas civilizaciones...", op. cit., págs. 197-198.

12 Los epígrafes de Hurviedro, que se alegaban como indicativo de una pretendida administración que se remontaría a la época de Salomón, son pura invención. Ver al respecto AmADOR DE LOS Ríos, J., "Historia social de los judíos...", op. cit., págs. 35-36; KATZ, S., "The Jews in the Visigothic...m, op. cit., págs. 144 y ss.; CANTERA, F. y MILLÁS, J. M., "Las inscripciones...", op. cit., págs. 29 y ss., n. ${ }^{\circ} 210$ y ss.

13 Para las leyendas recogidas por Rabí Isaac Abrabanel y por Salomón Ibn Vega, que se remontan a relatos anteriores, ver BEINART, I., "iCuándo...", op. cit., págs. 12-13; ASHTOR, E., The Jews of Moslem Spain I. Filadelfia 1973, pág. 306; BEINART, H., Los comienzos del judaismo español. Buenos Aires 1973, que no hemos podido consultar; García IgLESIAS, L., Los judíos en la Hispania antigua. Madrid 1978, pág. 37. 
trayectoria cultural de algunos pueblos, corrientes artísticas ambiguas, imprecisas, que se remontan a épocas prehistóricas. ¿Qué razones acosejan desechar estos relatos y leyendas judíos, mientras que, por otra parte, no se generalizan con firmeza las actitudes negativas a la hora de utilizar ese material legendario de otros pueblos o utilizarlo con minuciosas medidas cautelares? Hay una diferencia inicial entre un caso y otro. El acervo cultural de muchos pueblos se ha mantenido por inercia y de forma natural a lo largo del tiempo. Por el contrario, las leyendas judías indicadas toman cuerpo en la Edad Media animadas con una intencionalidad concreta. La Edad Media, aunque dispuso de momentos matizados de tolerancia hacia el pueblo judío, estuvo caracterizada, en términos generales, por un fuerte antisemitismo. Una parte no pequeña, y tampoco la única, en la composición de este antisemitismo la constituyeron las confrontaciones y contrastes religiosos entre judíos y cristianos. Estas leyendas y relatos legandarios, a los que se pretende dar un carácter histórico, buscan justificar un temprano asentamiento judío en España. Con ello se quería hacer ver a los cristianos de época medieval que los judíos de España, al menos, quedaban a resguardo de cualquier sospecha de estar implicados por vía de descendencia en la muerte de Jesús ${ }^{14}$. Pero no creo que el valor y la posibilidad de utilización de relatos fantásticos y leyendas dependa de una cuestión de intencionalidad, sino de la falta de garantías de fiabilidad y de la carencia de elementos seguros y localizables con precisión en el tiempo que sean susceptibles de una cómoda utilización sin riesgos. Cuando se dice que son relatos basados en tradiciones anteriores -y esto es algo en lo que coinciden los investigadores modernos que recogen y utilizan dichas leyendas-, se está dando a entender que se trata de algo, en la cantidad y la calidad que sea, que se remonta a épocas anteriores ${ }^{15}$. $Y$ esta imprecisa connotación de remota antigüedad pudiera

14 En la moderna investigación, es una opinión bastante generalizada el considerar que este tipo de relatos se desarrollan en épocas poco propicias a los judíos, con la intencionalidad de demostrar y de justificar que en el Peninsula la presencia judía es muy antigua. Con ello los judíos hispanos y sus ancestros quedaban exculpados de cualquier implicación histórica en la muerte de Jesús. Ver al respecto, WILLIAMS, A. L., Adversus ludaeos. A bird's eye view of christian "Apologie" until the Renaissance. Cambridge 1935, pág. 208; CunHA AzEVEdo, E., O sefardismo nacultura portuguesa. Oporto 1974, págs. 16-17; VALLE Rodriguez, C. del, El mundo judío. Madrid, UNED, 1976, pág. 276; Garcia IgLESIAS, L., Los judíos en la España antigua. Madrid 1978, pág. 38.

${ }_{15}$ El papel de la tradición en las composiciones históricas ha sido estudiado por MomiGLIA. No, A., "Historiografía sobre tradición escrita e historiografía sobre tradición oral" e «Historiografía griega", en La Historiografía griega, vers. cast. Barcelona 1984, págs. 94-104 y 9-38. Este autor señala que, en sus obras tanto Heródoto como Tucídides se han estado guiando por el conocimiento que proporciona la contemplación directa de los acontecimientos y por el testimonio que ofrece !a tradición oral ofrecida por aquellos testigos presenciales de los hechos, más que por la indagación histórica suministrada por los testimonios escritos. Es cierto que en ocasiones tampoco Heródoto ha dejado de considerar oportuno registrar acontecimientos que 
parecer que otorga a dicho relato, al menos aparentemente, una presunta y ambigua validez sobre la que se articula el titubeante argumento de una antiquísima presencia judía en España. ¿Pero hasta qué momentos remontamos el núcleo originario y la matriz de ese relato fantástico? ¿A la época visigoda?, ¿a la romana?, ¿a la prerromana? Desconocemos, por lo pronto, no sólo cuál pudo ser el núcleo original de esas tradiciones y los datos concretos en los que se apoyaban, sino la fecha a la que podían remontarse. $Y$, si desconocemos eso, con mayor razón tendremos que estar en ayunas respecto de los avatares sufridos por ese núcleo a lo largo del tiempo, y los posibles nuevos elementos y adherencias que se irían incorporando a su andadura temporal como reflejo de posturas mentales que evolucionan en lo largo del tiempo.

Otros indicios esgrimidos para apuntalar una posible y remota presencia judía en España se han apoyado en la interpretación específica que se ha hecho de un concreto pasaje bíblico. Jonatán Ben Uziel, perteneciente a la escuela del célebre rabino Hillel ${ }^{16}$, identifica con España la única mención bíblica de Sefarad contenida en el pasaje de Abdías 20 "y los cautivos de Jerusalén que están en Sefarad ocuparán las ciudades del mediodía" ${ }^{17}$. Los comentaristas judíos, que posteriormente se enfrentaron con este pasaje, continuaron propalando dicha identificación, a partir de la cual se utiliza el nombre de sefardita para denominar a los judíos españoles o de procedencia hispana ${ }^{18}$. En el caso de que esa identifi-

no podian verificarse oportunamente. Pero tal cosa se ha hecho con las cautelas pertinentes. Ciertamente estos autores hacían uso prevalente de la tradición oral; pero también es cierto que los criterios utilizados en su adopción no carecian de rigurosidad, por cuanto que, o bien se requería que el historiador fuese testigo de los acontecimientos, o bien se exigía que los hechos narrados o contados por otros estuviesen sometidos al contraste de la verosimilitud. En otras palabras, estaban animados de un sincero afán de separar los hechos, reales o ficticios, de las meras fantasias.

16 Para el desarrollo e importancia de la casa de Hillel, ver MAIER, J., Grundzüge der Geschichte des Judentums im Altertum. Darmstadt 1981, págs. 96 y ss. y 111 y ss. La ascendencia, que el Sumo Sacerdote tenía sobre Israel, se ejercía también sobre la Diáspora. Ya Julio César añadió el título de "ethenarca" al de Sumo Sacerdote que tenía Hircano II. Ver con relación a la denominación de "etnarca de los Judíos" lo que dice Momigliano, A., Ricerche sull'organizzazione della Giudea sotto il dominio romano (63 a.C.-70 d.C.). Bolonia 1936; $2 .^{\text {a }}$ ed. Amsterdam 1967. En la casa de Hillel, esto era hereditario, ver Sullivan, R. D., "The Dynastia of Judaea in the First Century", ANRW, II, 8. Berlín-Nueva York 1977, págs. 296 y ss. Sobre la escuela de Hillel y sus diferencias respecto de la escuela de Shammai, ver SONNE, 1., “The Schools of Shammai and Hillel seen from Within", en Ginzberg Jubilee volume on the Occasion of his Seventieth Birthday. Nueva York 1945, págs. 275-291 con bibliografía; GutTManN, A., "Hillelites and Shammaites. A clarification", Hebrew Union College Annual, n. ${ }^{\circ}$ 28, 1957, págs. 115-126.

17 Traducción tomada de Nácar, E. y ColungA, A., Sagrada Biblia. Versión directa de las lenguas originales, $9 .^{a}$ ed. Madrid 1971.

${ }_{18}$ La cuestión etimológica de la palabra Sefarad ha sido abordada por GonzALO MAESO, D., "Sobre la etimología de la voz Sefarad", Sefarad, n. ${ }^{\circ}$ IV, 1944, págs. 359-363. Ver también lo que dice sobre su arraigo en la literatura hebraica LAREDO, A. I., "Sefarad en la literatura he- 
cación pudiera ser correcta, tendríamos consecuentemente que admitir la innegable existencia de una importante comunidad judía en España por efecto inducido de la diáspora provocada por Nabucodonosor. El profeta está prediciendo la vuelta a la patria de los judíos dispersos por doquier, especificando entre ellos, en concreto a los judios residentes en Sefarad. Al margen de la cuestión de la identificación, como cuestión de fondo, no parece muy verosímil históricamente que la dispersión judía de la época de Nabucodonosor hubiese alcanzado tierras tan alejadas como las hispanas y muchos menos en la cuantía que presupone el pasaje bíblico, aun contando con el hecho de que el lenguaje profético es proclive a la exageración. Pero es que, además, estamos en condiciones bastante seguras de no asumir como válida esa identificación y, por tanto, la posibilidad, derivada de esa identificación, de la existencia de una temprana presencia judía en España. Y a esta conclusión se llega por la alta y sólida fiabilidad de que la identificación correcta de la biblíca Sefarad es con Sardis, que en persa se denomina Sapparda ${ }^{19}$.

\section{INDICIOS MÁS SEGUROS}

Todas las reflexiones. que pretendan sugerir como factible una temprana presencia judía en España, deberán, inevitablemente, ponerse en relación con la colonización fenicia del Mediterráneo occidental ${ }^{20}$. Feni-

braica", Sefarad, n. IV, 1944, pág. 356; Gonzalo MAESo, D., Historia de la literatura hebrea. Madrid 1960, págs. 390-391. NEIMAN, D., "Sefarad, the name of Spain", Journal of Near Eastern Studies, n. 22,1963 , págs. 128 y ss. Sobre este pasaje de Abdías, ver KORNFIELD, W., “Die judische Diaspora in Ab. 20", en Melanges A. Roberb. París 1957, págs. 180 y ss.

19 Ver al respecto KraAbel, A. T., "Hysistos and the Synagogue at Sardis", Greek Roman and Byzantine Studies, n. ${ }^{\circ}$ 10, 1969, pág. 81; PEDLEY, J. G., Ancient literary sources on Sardis. Cambridge 1972, págs. 85 y 305-306; CORNFIELD, G., Arqueologia de la Biblia de Abraham a Jesús, ver. cast. Buenos Aires 1980. García IGLEsIAS, L., "Los judíos...», op. cit., pág. 36.

${ }^{20}$ Es interesante la panorámica general de la expansión fenicia proporcionada por CARPENTER, R., "Phoenicians in the West", AJA, n. ${ }^{\circ} 62,1958$, págs. 35-53; CuLICAN, W., "Aspectos of Phoenician Settlement in the West Mediterranean", Abr-Nahrain, n. ${ }^{\circ}$, 1961, págs. 36-55. Visiones importantes pueden contemplarse en Moscatı, S., L'épopée des Phéniciens, vers. franc. París 1971. Pueden percibirse nuevas aportaciones por varios especialistas en Las Actas de L'espansione fenicia nell Mediterraneo. Roma 1971; NIEMEYER, H. G. (ed.), Phönizier im Westen. Maguncia 1982.

Para el conocimiento de la expansión fenicia en espacios geográficos más concretos hay que destacar los testimonios arqueológicos procedentes de Cerdeña. Esta isla, no muy alejada de las islas Baleares y de las tierras orientales de España, recibió importantes asentamientos fenicios de los que proceden muchos objetos. Éstos, y restos de edificaciones, han proporcionado un importante conocimiento de la expansión fenicia en tierras próximas a las hispanas. Para las últimas referencias bibliográficas, ver TORE, G., "Sardinia antiqua: bibliografia feniciopunica", Biblioteca Francescana Sarda, III, 2, 1989. Oristano 1991, pág. 377. Ver también BA. RRECA, F., La civiltà fenicio-publica in Sardegna. Sassari 1986; BARTOLON1, P., "Contributo alla 
cios e israelitas mantuvieron una estrecha colaboración económica y social, que queda reflejada en algunas referencias bíblicas; entre otras, $I$ Reyes IX, 26-28, en la que se indica que naves israelitas de Salomón traficaron de una forma coordinada con naves fenicias del rey Hiram de Tiro y la de I Reyes $X, 22$, en la que se señala que en naves de Tarsis se transportaba oro, plata, marfil, monos y pavos reales ${ }^{21}$. $Y$ el caso es que otros investigadores han utilizado los datos que proporcionan esas referencias bíblicas como indicativo de la existencia de actividades comerciales fenicias en el Mediterráneo occidental y en España en particular, con anterioridad incluso a los momentos en los que, como magistralmente ha sintetizado M. E. Aubet, comienzan a aparecer en España los testimonios arqueológicos como prueba de ese comercio fenicio ${ }^{22}$. Las diversas opiniones e hipótesis, emitidas por los investigadores en torno a

cronologia delle necropoli fenicie e puniche di Sardegna", $R S F$, n. ${ }^{\circ} 9,1981$, págs. 13-29; MosCATI, S., Italia punica. Milán 1986; BoNDI, S. F., "La Sicilia fenicio-punica: Il quadro storico a la documentazione archeologica", Bollettino d'Arte, $\mathrm{n} .{ }^{\circ \mathrm{s}} 31-32,1985$, págs. 13-32. Para España, ver Pellicer, M.; Menanteau, L. y Roulllard, P., «Para una metodología de localización de colonias fenicias en las cosas ibéricas: el cerro del Prado», Habis, $n .^{\circ} 8,1977$, págs. 217-251; GASULL, P., "Problemática en torno a la ubicación de los asentamientos fenicios en el sur de la Península Ibérica”. Aula Orientalis, n. ${ }^{\circ} 4,1986$, págs. 193-202.

${ }_{21}$ Analistas bíblicos como $\mathrm{G}$. Cornteld, sitúan cronológicamente estos datos entre los años 965-928 a.C., "Arqueología de la Biblia...», op. cit., págs. 123-125. Para la importancia alcanzada por el estado israelí durante esta época, ver HEATON, E. W., Salomon's new men. The Emergence of Ancient Israel as a National State. Londres 1974.

${ }_{22}$ Aubet, M. E., Tiro y las colonias fenicias de Occidente. Barcelona 1987, aunque el libro aborda la cuestión fenicia dentro de un contexto geográfico más amplio, estudia con detenimiento el problema de la presencia fenicia en España, aportando, entre las págs. 279-284, numerosas referencias bibliográficas. Ver también AUBET, M. E., "Aspectos de la colonización fenicia en Andalucía durante el siglo viı a.C.", Atti l Congreso Internazionale di Studi Fenici e Punici, III. Roma 1983, págs. 815-824. Visiones de conjunto en BLÁzQUEZ, J. M., “Las colonizaciones semitas en Huelva, Cádiz y la Baja Andalucia», Papeles de/ Laboratorio de Arqueología de Valencia, n. ${ }^{\circ} 11,1975$, págs. 207-250; MuNiz, J., "Málaga y la colonización púnica en el Sur peninsular", Habis, n. ${ }^{\circ}$, 1974, págs. 109-129; LoPEz MONTEAGUDO, G., "Panorama actual de la colonización semita en la Península Ibérica», RSF, n. ${ }^{\circ}$ 5, 1977, págs. 155-204; TreumanN, B. W., "West-phoenician Presence of the Iberian Peninsula", en The Ancient World, n. ${ }^{\circ} 1,1978$, págs. 15 y ss.; Schubart, H., "Asentamientos fenicios en la costa meridional de la Península lbérica», en Huelva Arqueológica, n. ${ }^{\circ} 6,1982$, págs. 71-99.

Para los poblados y necrópolis fenicias, ver Aubet, M. E.; MaAss-Lindemann, G. y Schubart,

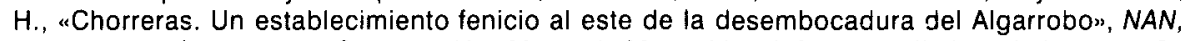
n. ${ }^{\circ} 6,1979$, págs. 89-138; SHUBART, H., «Morro de Mezquitilla. Informe preliminar de la campaña de excavaciones de 1981 en el Morro de Mezquitilla, cerca de la desembocadura del río Algarrobo", NAH, n. ${ }^{\circ} 19,1984$, págs. 85-101; PELLICER, M., "Sexi fenicia y púnica", Aula Orientalis, n. ${ }^{\circ}$ 3, 1986, págs. 85-107; Ruiz MATA, D., "Castillo de Doña Blanca (Puerto de Santa Maria, Cádiz). Stratigraphische Untersuchung einer orientalisierenden Ansiedlung», $M M, n .{ }^{\circ} 27,1986$, págs. 87-115; Arribas, A. y WiLkINS, J., "La necrópolis fenicia del Cortijo de las Sombras (Frigiliana, Málaga)", Pyrenae, n. ${ }^{\circ}$ 5, 1969, págs. 186-244; Schubart, H. y Niemeyer, H. G., "Los hipogeos fenicios y el asentamiento en la desembocadura del Algarrobo", en Excavaciones arqueológicas de España, n. ${ }^{\circ} 90$. Madrid 1976. 
las primeras fundaciones fenicias, resultan de difícil conciliación. En este sentido, las fechas que las fuentes literarias ofrecen para las fundaciones de Gadir, Utica y Lixus, y que remitían a una época tan remota como el siglo xII a.C., se acomodan muy mal con los datos arqueológicos. El intento de armonizar estos dos elementos de entidad diferente crea un importante abismo cronológico, que es lo que provocó la adopción de diveras posturas con relación a las fechas en las que pudieron haber tenido lugar los primeros asentamientos fenicios. En el 1971, A. García y Bellido ${ }^{23}$, aunque reconocía que los datos arqueológicos no se remontan más alla del siglo vilI a.C., consideraba que las diversas posturas podían conciliarse. A este respecto decía "es preciso admitir que, si para los siglos VIII-VII a.C. tenemos ya tantos testimonios, ello quiere decir que antes de esas fechas hubo de haber un largo período de exploraciones y de contactos comerciales que hiciesen posibles los abundantes testimonios de los siglos VIII y VII». Admite, por tanto, la existencia de un período de presencia fenicia en la Península Ibérica anterior a la constatación arqueológica. Este período, que en España pudiera muy bien situarse entre finales del siglo $x$ a.C. y principios del siglo vill a.C., estaría caracterizado por expediciones comerciales, que practicaran el trueque con los indígenas y que serían los responsables de la presencia en España de algunos objetos esporádicos como los marfiles decorados procedentes de Carmona, que se sitúan en el siglo vIII a.C.; el cuenco procedente de Berzocana, que correspondería a los siglos XII-X a.C., y los bronces de la ría de Huelva, al siglo ix a.C. Pero to cierto es que todos estos objetos, al estar fuera de contexto arqueológico, pierden fuerza en su utilización como indicativo de esta fase precolonial ${ }^{24}$.

\footnotetext{
149-150.

${ }^{24}$ A este respecto, WHITTAKen, C. H., «The Western Phoenicians: colonization and assimilation", Proceedings of the Cambridge Philological Society, $n .^{\circ} 20,1974$, págs. 58 y ss., distingue dos fases: la primera hasta el siglo vill a.C., está caracterizada por un comercio esporádico; durante la segunda, a partir de ese siglo, se realizan importantes asentamientos. AUBET, M. E., "Tiro y las colonias...", op. cit., pág. 181, mantiene sus reservas metodológicas respecto a la aceptación de esa fase precolonial, que algunos suponen que aconteció entre finales del siglo $x$ a.C. y principios del siglo viu a.C. Con esas precauciones metodológicas considera que esas tempranas expediciones comerciales que otros proponen, pudieran tratarse de expediciones comerciales semejantes a las que realizaban las naves de Hiram y de Salomón uque viajan cada tres años en busca de metales". Para esa fase pre-colonial fenicia, ver NIEMEYER, H. G., "Anno octogessimo post Troiam captam... Tyria classis Gadis condidit? Polemische Gedanken zum Gründungsdatum von Gades (Cádiz)", Hamburguer Beiträge zur Archäologie, n. ${ }^{\circ} 8,1981$, págs. 9-33; MoscatI, S., "Precolonizzazione greca e precolonizzazione fenicia», RSF, n. ${ }^{\circ} 11,1983$, págs. 1-7; BısI, A. M., "Le "Smiting God" dans les milieux phéniciens d'Occident", Studia Phoenicia, n. ${ }^{\circ} 4,1986$, págs 169-187. Sobre los marfiles fenicios en la Península, ver AUBET, M. E., Marfiles fenicios del Bajo Guadalquivir. Valladolid 1978-1980.
} 
En la Península lbérica este comercio fenicio se realizaba predominantemente con Tartessos, denominación que se atribuye a una cultura específica desarrollada en las tierras meridionales de España. Desde que en la década de los cuarenta A. Schulten publicó su monografía sobre Tartessos, nuevas valoraciones de los materiales ya conocidos desde perspectivas metodológicas diferentes, nuevos hallazgos, nuevos planteamientos, han llevado a una mejor comprensión de los componentes esenciales de la cultura tartésica, a su evolución, a la singularización de un período orientalizante, a la identificación de los aportes del mundo colonial y a sus influjos en el mundo indígena. Recogeré en nota algunos de los muchos trabajos que abordan este tema ${ }^{25}$, haré, no obstante, la rápida consideración de que, aunque desde el campo de la Arqueología y a partir de la evidencia material se está en condiciones de plantear preguntas interesantes e importantes, no por ello se cuenta con respuesta satisfactorias.

Pero, al mismo tiempo que de la mano de la Arqueología se producía la renovación indicada en el conocimiento de la cultura material y del mundo colonial, tenía lugar también la revisión crítica de aquellos pasajes bíblicos, griegos y latinos, en los que se alude al comercio fenicio en Occidente ${ }^{26}$, y en los que se menciona a Tarsis. Era éste un término de

25 Desde la monografía de Schulten, A., Tartessos. Madrid 1945, han proliferado los trabajos relacionados con este tema. No son pocos los trabajos que con machacona reiteración han insistido en los problemas a los que da lugar la enigmática cuestión tartésica. Varias de las cuestiones relacionadas con los componentes constitutivos de la cultura tartésica y sus relaciones con fenicios y griegos, quedan esbozadas en el libro de MaLUQUER DE MOTES, J., Tartessos. Barcelona 1970. Cuestiones y relaciones que J. M. BLAZQUEZz estudiará mucho más ampliamente en su obra Tartessos y los origenes de la colonización fenicia en Occidente, 2 a $^{a}$ ed. Salamanca 1975, avalada por numerosas referencias bibliográficas, anteriores al año de su reedición. Para años posteriores, y por lo que hace a las referencias literarias, ver de este mismo autor el capítulo dedicado a Tartessos en VV.AA., Historia de España. 2. Colonizaciones y formación de los pueblos prerromanos (1200-218 a.C.). Madrid 1989, págs. 71-78. Para el proceso de aculturación tartésica, los elementos protourbanos de la cultura tartésica y las dificultades que plantea la composición de los elementos constitutivos de esa cultura, ver WAGNER, C. G., "Aproximación al proceso histórico de Tartessos", AEA, n. ${ }^{\circ} 56,1983$, págs. 3 y ss.; ABAD, L., "Consideraciones en torno a Tartessos y el origen de la cultura ibérica", $A E A, n{ }^{\circ} 52,1979$, págs. 181-184

Son varios los trabajos que han contribuido a delimitar un período orientalizante. Para las líneas maestras y los elementos que componen ese período orientalizante en un área concreta, ver Almagro Gorbea, M., El Bronce Final y el Periodo Orientalizante en Extremadura. Madrid 1977. Para otra región distinta ver GARRIDO, J. P., "Mundo indígena y orientalizante en la región del Tinto-Odiel», AEA, n. ${ }^{\circ} 52,1979$, págs. 39 y ss. Para los problemas relacionados con este período, ver AUBET, M. E., "Algunas cuestiones en torno al período orientalizante tartésico", Pyrenae, n. ${ }^{\text {os }} 13 \cdot 14,1979$ y "La aristocracia tartésica durante el período orientalizante", Opus III, 1984, págs. $445-468$.

${ }^{26}$ Las tradiciones literarias están adecuadamente analizadas en BUNNES, G., L'expansion phénicienne en Méditerranée. Essai d'interprétation fondé sur une analyse des traditions litté- 
referencia, que, ya desde tiempos antiguos, se abrió a diversas interpretaciones respecto al lugar geográfico al que debía corresponder. Lo cierto es que en el Antiguo Testamento la palabra Tarsis se utiliza en forma diversa: a veces parece un antropónimo, otras designaría una piedra preciosa, en ocasiones un tipo de nave y, finalmente, un lugar geográfico ${ }^{27}$. Todos esos sentidos interesan a nuestra consideración, si bien el toponímico resulta en especial relevante. Pero, incluso dentro de este valor concreto de topónimo, las actuales corrientes de opinión predominantes, apoyadas en las mismas referencias bíblicas, se distribuyen entre la tendencia que propone una localización de la Tarsis bíblica en la zona del Mar Rojo y aquella otra que la sitúa en el Mediterráneo occidental, en tierras de Tartessos ${ }^{28}$. Esta controversia sobre las posibles identificacio-

raires. Bruselas-Roma 1979, págs. 333-347. Para las fuentes griegas y latinas, ver también BLÁzQUEZ, J. M., "Fuentes griegas y romanas referentes a Tartessos", en Tartessos. V. Symposium Internacional de Prehistoria Peninsular. Barcelona 1969, págs. 91-110.

${ }_{27}$ En el Antiguo Testamento la palabra Tarsis se utiliza para designar varias cosas. Es un antropónimo (Génesis X,4; cf. I Crónicas I,7, VII, 10; Ester, I,14), otras veces designa una piedra preciosa (Éxodo XXVIII, 20; XXXIX,13; Ezequiel, I,16, X,9, XXVIII,13; Danie/ X,6; Cantar de los Cantares V,14), un tipo de barco bajo la expresión naves de Tarsis (I Reyes $\mathrm{X}, 22$, XII, 49; Isaias II,16, XXIII, 1 y 14, LX,9; Ezequie/ XXVII,25; Salmos XLVIII,8) y a menudo asume el significado de un lugar geográfico (II Crónicas IX,21, XX,36 y 37; Isaias, XXIII,6 y 16; LXVI,19; Jeremías X,9; Ezequiel XXVII, 12, XXXVIII,13; Jonás I,3, cf. IV,2; Salmos LXXII). Naturalmente, estos pasajes no pueden utilizarse indistintamente. No todos ellos responden a los mismos momentos cronológicos, ya que su empleo se extiende durante 400 años. Su uso como topónimo no es anterior al siglo vi a.C., ver AUBEt, M. E., "Tiro y las colonias...", op. cit., págs. 184 y ss. Y no serán éstos los únicos usos. También se ha intentado interpretar Tarsis con el valor semántico de "mar», Hóning, S. B., "Tarshish", JQR, n. ${ }^{\circ} 69,1979$, págs. $181-182$, cosa que parece poco probable. Otros autores, estudiando la raíz RSS desde el punto de vista filológico, la ponen en relación con Tarsis y consideran que con este término se designaba a regiones metalúrgicas y mineras en razón del significado de "fundir" con la que se suele interpretar la raiz en cuestión. Ver ALbaight, W. F., "New light in the early history of Phoenician colonization", BASOR, n. ${ }^{\circ} 83$, 1941, págs. 21-22; SOLÁ SOLÉ, J., «Tarshish y los comienzos de la colonización fenicia en Occidente", Sefarad, $n .^{\circ} 17,1957$, págs. 33-35. También se ha sugerido la posible localización de la Tarsis bíblica en las tierras del Mediterráneo occidental, en la idea de que la secuencia btrss de la estela de Nora - situada cronológicamente en el siglo ix a.C., por criterios epigráficos-, pudiera albergar una mención a Tarsis. Sobre esta inscripción, ver Cross, F. M., "An interpretation of the Nora Stone", BASOR, n. ${ }^{\circ}$ 208, 1972, págs. 15-16; AMADASI, M. G. y Guzzo, P. G., "Di Nora, di Eracle gaditano e della piú antica navigazione fenicia", Aula Orientalis, n. IV, 1986, págs. 58-71; RoLLIG, W., “Paläographische Beobachtungen zum ersten Auftreten der Phönizier in Sardinien", en Festschrift J. Thimme. Karlsruhe 1983, págs. 125-130.

${ }^{28}$ Para la identificación, que no es defendida por muchos autores, de Tarsis con Cartago, ver Herrmann, A., "Die Tartessosfrage und Weisafrika", Petermans geographische Mitteilungen, n. ${ }^{\circ} 78,1942$, págs. 354-356. Entre los autores que se inclinan por situar la Tarsis bíblica en el Mar Rojo se encuentra TäckHOLM, U., "Tarsis, Tartessos und die Saülen des Herakles", Opuscula Romana, n. ${ }^{\circ} 5,1965$, págs. 143-160; idem, "Neue Studien zum Tarsis-Tartessos-problem», Opuscula Romana, $n .^{\circ} 10,1974$, págs. 41-57. Piensan que Tarsis hace referencia a Tarso de Cilicia, entre otros autores, GARBINI, G., que aporta los siguientes trabajos, "Tarsis e Gen. 10.4", $\mathrm{BeO}, \mathrm{n} .{ }^{\circ} 7,1965$, págs. 13-19; I fenici. Storia e religione. Nápoles 1980 , págs. 95-116. Son más numerosos los autores que identifican a Tarsis con Tartessos. Entre éstos, CINTAS, P., "Tarsis- 
nes ha dado lugar, y sigue dando lugar, a una abundante producción científica, pero, para el tema objeto de nuestra consideración, esto es, la posibilidad de una temprana presencia judía en España, la problemática identificación Tarsis = Tartessos sólo reviste una importancia secundaria. $Y$ ello es así porque, se acepte o no tal identificación, el elemento primordial y el factor condicionante se concreta en la cuestión de si existen - no impedimentos históricos serios que obliguen a rechazar y a considerar inverosímil una eventual cooperación y coordinación comercial entre judios y fenicios. Salomón habia sabido aprovechar ciertamente las ventajas de la situación geográfica de Israel entre pueblos como los de Arabia, Siria y Egipto, para, en unión de los fenicios de Tiro, hacerse con un lugar importante en el comercio internacional. Las naves de Salomón, construidas quizá con la colaboración de especialista de Tiro, se incorporaron decididamente a las actividades comerciales y mercantiles. Expediciones aisladas y expediciones conjuntas con los fenicios, acercaron las naves de Salomón hasta tierras tan lejanas como las de Ofir (isur de Arabia?, ieste de África? o ¿la India?). Mercaderes del rey israelita (I Reyes 9, 26-27; Cr. 8, 17-18) Ilegaron hasta Kué (Asia Menor) para comprar caballos. Comprobada como está históricamente esta cooperación fenicio-israelita, que se materializó en expediciones por diversas rutas comerciales, tendría poco sentido el concluir que dicha cooperación tuvo un alcance geográfico limitado, concretamente a las tierras orientales. Sobre una hipótesis de este tipo recaería la carga de la prueba, y no parece que se disponga de datos probatorios. Cabe, por tanto, sacar la conclusión general de que no se perciben impedimentos históricos serios que cierren el camino a la posibilidad de una temprana presencia judía en España. Y, una vez establecida esta posibilidad, la pregunta que resulta pertinente hacerse es bajo qué forma y con qué cobertura fenicia llegaron algunos judíos a España. En este sentido, no está de más señalar, como ha especificado $M$. Koch, que en determinados momentos de la colonización fenicia, no es improbable que se haya producido la utilización de judíos como esclavos y como asalariados ${ }^{29}$. Consecuentemente, y aunque

Tartessos-Gades", Semitica, n. ${ }^{\circ} 16,1966$, págs. 5-37; KoCH, J. B., "Tarschich und Hispanien", Madrider Forschungen, $\mathrm{n} .{ }^{\circ} 14,1984$; TSIRKIN, J. B., "The Hebrew Bible and the Origin of Tartessian Power", Aula Orientalis, n. ${ }^{\circ}$ 3, 1985, págs. 179 y ss.; TYLOCH, W., “Le problème de Tarsis à la lumière del a philologie et de l'exégèse”, en Deuxième Congrès International d'Etudes des Cultures de la Mediterranée Occidentale. II. Argel 1978, págs. 46-50.

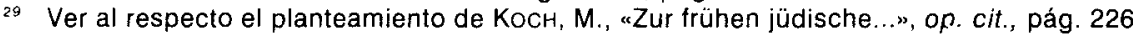
con apoyo, entre otros, en los siguientes pasajes y referencias bibliográficas, Ri. 5. 17. Ver $V_{A u X}, R$. de, Das Alte Testament und seine Lebens Ordnungen. Freiburgo 1960, págs. 127 y s. para jornaleros israelitas al servicio de los fenicios. A esclavos judíos se refiere Am. 1. 9; Jo. 4. $6 \mathrm{~s}$. Con relación a la problemática datación de estos pasajes, ver RudoLPH, W., "Amos; Joel", KAT XIII.2. Gütersloh 1971. KoCH, M., en la nota 6, ofrece más referencias. 
la reflexión siguiente no rebasa las barreras de la especulación, es posible, e históricamente bastante probable, que algunos judíos se hayan podido asentar en las zonas peninsulares exploradas por los fenicios, como personas libres, jornaleros y esclavos. $Y$, por otra parte, la representación de las relaciones de los israelitas con Tarsis resultaria inimaginable sin el concurso de las expediciones fenicias camino de las tierras occidentales. Esa misma posibilidad de un cierto goteo de judíos hacia España sería viable en relación con los años en que los cartagineses impusieron su dominio en algunas de nuestras tierras ${ }^{30}$.

En otro orden de cosas, no es inverosímil, como hemos visto, antes al contrario parece muy probable, que judíos aislados viniesen a España asociados a los fenicios. Sin embargo, resulta mucho más difícil el argumentar y el admitir que esos supuestos y tempranos asentamientos judíos se hayan perpetuado a lo largo del tiempo con sus rasgos diferenciadores en lo cultural. $Y$, aunque no se dispone de la pertinente información que pudiera proyectar al respecto alguna luz, esto nos lleva a considerar otra cuestión que no es nimia. Cuando hablamos de temprana presencia de judíos en España, parece como si asumiésemos implícitamente el término judío, única o primordialmente en una dimensión etnicogeográfica. Pero, una vez desarraigados de su tierra natal hebrea, es preciso preguntarse de qué modo asumieron su pertenencia al pueblo judio aquellos primeros judíos que se asentaron en la Península, y qué idea se formaron de los componentes constitutivos que configuraban la idiosincrasia judía.

Ciertamente, con anterioridad al exilio, el yahveismo había mantenido vivo y había desarrollado el patrimonio moral y cultural del pueblo de Israel, que fue cristalizando en unos principios fundamentales, cuya aplicación en la vida práctica se fue haciendo cada vez más firme y asidua. Durante el exilio, las gentes deportadas se habían ido constituyendo como pueblo en torno a ese patrimonio moral y a las normas que lo regían. $Y$

30 $\mathrm{KoCH}$, M., “Zur frühen jüdische...", op. cit., pág. 228, participa de la opinión de que Salomón no sólo tenía grandes intereses comerciales en la parte oriental del Mediterráneo, sino también en la occidental. Apoya esta suposición en el pasaje 1 Re. 10.28 con el que Rüger, $H$. P., Calwer Bibellexikon, 1959, comienza su análisis de la diáspora judia anterior al Exilio. Con esta opinión no está muy de acuerdo $M$. Koch. Al aludir al trabajo de M. Koch, BLÁzQUEZ, J. M., "Tartessos", en "Historia de España. Colonizaciones y formación de los pueblos...», op. cit., pág. 77, cree oportuno exponer su propia opinión, considerando como probable que Salomón tuviese agentes comerciales en Occidente, junto con los fenicios que le procurasen metales; y concluye upudieron llegar esclavos judios con los cartaginenses y griegos, que no había colonias judias ni sinagogas. Somos de la opinión de que a finales de la República debió haber ya juderias importantes en la Península lbérica". 
esto era algo que les proporcionaba una coherencia interna y daba sentido a sus vidas. Constituía un lazo que los mantenía unidos con su pasado y será lo que propiciará su resurgimiento nacional ${ }^{31}$. Pero, en el caso de los judios de España, la situación parece ser un tanto diferente. No se trata de gentes procedentes del exilio, ni constituyen grandes contingentes de deportados. Su llegada ha podido tener lugar en momentos anteriores a ese exilio durante el cual se fue reforzando el sentido de unidad judía. Además, posiblemente los que pudieron llegar a España fueron muy pocos y no los más selectos, de modo que la percepción que pudieran tener de sus peculiaridades culturales, morales y religiosas no debió de ser muy fuerte ${ }^{32}$ : muy inferior, cuando menos, a la de los intelectuales en-

31 Con relación a este período y al inmediatamente posterior se encuentran varios pasajes de los libros bíblicos, Ezequiel, Deuteroisaias -en la redacción del libro de Isaias se perciben varios autores; al "Segundo" le corresponderian los capítulos 34 a 55--, Ageo, Zacarías, Malaquías, Crónicas, Esdras-Nehemias, ver los capítulos correspondientes en EISSFELDT, O., Einleitung in das Alte Testament, $3{ }^{a}{ }^{2}$ ed. Tübingen 1964. La información sobre el Exilio de Babilonia la proporciona el libro de Ezequiel, profeta que también padeció el Exilio. Durante su cautividad, el pueblo judío logró mantener su originalidad y su fe. Sus tradiciones durante el Exilio se mantuvieron incluso con mayor rigor. Profetas como Ezequiel alimentaron la esperanza en la restauración en la que Jerusalén sería el centro de un estado teocrático regido por la ley de Yahvé. En este sentido, hay que tener presente que, tras la caída de Babilonia, Ciro ordenó la restauración del Templo que se acabará en el reinado de Dario. Ver VAuX, $R$. de, "Les décrets de Cyrus et de Darius sur la reconstruction du Temple", Rev. Bibl., n. ${ }^{\circ} 46,1937$, págs. 29 y ss., recogido también en Bible et Orient. París 1967, págs. 83 y ss. La politica persa con relación al pueblo judío, no fue muy diferente de la practicada con otros pueblos, ver ACKROVD, P. R., Israel under Babylon and Persia. Londres 1970; SMITH, M., Palestinian Partiesand Politics which Shaped the Old Testament. Nueva York-Londres 1971; GABRIEL, J., Zorobabel. Ein Beitrag zur Geschichte der Juden in der ersten Zeit nach dem Exil. Viena 1927.

${ }^{32}$ La situación política anterior al Exilio era muy diferente de aquella otra en la que se produjo la restauración del Templo de Jerusalén. En aquella situación, el Templo tenía su existencia dentro de una entidad política autónoma. En época aqueménida, las tierras israelitas se habían incorporado a la órbita de dominio persa. Con todo, el Templo no sólo era el polo de atracción religiosa y el lugar de culto para una comunidad, que está políticamente sometida, sino también para muchos otros que se encontraban en la Diáspora. Fuentes bíblicas como el Deuteronomio dan a entender que en Judea se habia producido un sincretismo de tendencias religiosas acompañado por un relativo relajamiento moral. La renovación de esa situación vino desde Babilonia. Nehemías, de la comunidad judía de Babilonia y funcionario persa, no sólo logró, con la oposición de los Samaritanos, el amurallamiento de Jerusalén - ver al respecto COGGINS, R. J., Samaritans and Jews. The Origins of Samaritanism reconsidered. Oxford 1975-, sino que restableció el equilibrio social, propiciando el rearme moral de la clase sacerdotal. Además, prohibió los matrimonios mixtos y exigió con mayor rigurosidad el cumplimiento del Sabbat. La comunidad judia de Babilonia siguió siendo el centro del rigorismo yahveista. Y de la comunidad judia de Babilonia procedia el sacerdote Esdras, que fue enviado a Jerusalén por el círculo yahveista de Babilonia, para imponer "la ley del Dios del cielo", el cumplimiento del Sabbat, el pago de ofrendas al Templo y la disolución de los matrimonios mixtos. Ver al respecto, RicciotTI, G., "Historia de Israel...”, op. cit., págs. 148-152. Con relación a la comunidad judía de Babilonia, ver OBERMAYen, J., Landschaft Babylonien im Zeitalter des Talmunds und Gaonats. Brelau 1938; NEUSNER, J., A history of the Jews in Babilonia, 5 vols. Leiden 1965-1970. 
viados al exilio ${ }^{33}$. Además, la venida de judíos a España en condición de esclavos, jornaleros o intermediarios ${ }^{34}$ hacia que su asentamiento normal se realizase en contextos coloniales y poblacionales fenicio-púnicos con los cuales tenian muchos puntos en común. Entre ambos sectores poblacionales se daba una relación de trato, mutua y dinámica, que enseguida abrió el camino hacia la asimilación y reabsorción de lo judio en las comunidades fenicias - e incluso en las comunidades indígenas - con peso decisivo estas comunidades fenicias en la composión étnica y en el predominio cultural. En tales circunstancias resulta extraño pensar en términos de resistencia o de persistencia de la identidad judía, cifrada en clave de peculiaridad religiosa - difícil, por otra parte, de sostenerse sin contar, como parece que no ocurría en aquellos momentos, y menos en pequeños grupos o familias aisladas, con una cuidadosa atención espiritual desde Jerusalén y, luego, desde las potentes comunidades judías de la diáspora ${ }^{35}$. Ciertamente, no hay datos arqueológicos, ni referencias

33 Durante el dominio persa, muchos lugares estratégicos estuvieron protegidos por guarniciones militares. Una de éstas la constituyó la comunidad judía de Elefantina. Su existencia parece remontarse a los momentos inmediatamente posteriores a la caída del reino de Judá, cuando algunos judíos fueron contratados, probablemente, como mercenarios. Esta comunidad de soldados judíos y sus familias han proporcionado una abundante documentación, que se extiende hasta hacia el 400 a.C.

Para los textos procedentes de Elefantina, ver la edición de Cowley, A., Aramaic Papyri of the 5th Century b.C. Oxford 1923; WITZEL, T., "Documenti aramaici del sec. v a J.C.", Rivista storico-critica delle scienze teologique, 1909, págs. 680 y ss.; HOONACKER, A. van, Une communauté Judéo-Araméenne à Eléphantine. Londres 1915; VINCENT, A., La religión des judéoaraméens d'Elephantine. París 1937; PORTER, B., Archives from Elephantine. Berkeley-Los Angeles 1968; SCHÜRER, E., Geschic hte des jüdischen Volkes im Zeitalter Jesu Christi III, $4 .^{\text {a }}$ ed Leipzig 1909, págs. 24-33 y 40-50, señala la antigüedad que tenía la judería egipcia. Ver también TSCHERIKover, V., Hellenistic Civilization and the Jews I. Filadelfia 1959, págs. 269-292. La comunidad judía de Elefantina mantenía buenas relaciones con las autoridades religiosas de Jerusalén, a las que remitia noticias acerca de la situación de la comunidad elefantina. Pero el ambiente circundante, y la lejanía geográfica de Jerusalén, hacia que en muchos aspectos dicha comunidad ofreciese rasgos peculiares. Asi, tenian un Templo a Jahvé, desconociendo, y si lo conocian no lo respetaban, la prescripción de que sólo en el Templo de Jerusalén era lícito celebrar la liturgia. Cuando el Templo de Elefantina fue destruido por los egipcios, los judíos de esa comunidad solicitaron infructuosamente de las autoridades religiosas de Jerusalén, permiso para su reconstrucción. Los judíos de Elefantina se mantenían, por tanto, fieles a su fe y a sus prácticas religiosas. Pero, a pesar de ello, por efecto del sincretismo y de la contaminación religiosa, dicha comunidad conjugaba su fe judaica con la creencia en otros dioses, a los que se destinaban (Papiro, 22. ${ }^{a}$ ed. Cowley) ofrendas similares a las consagradas a Yahvé, ver RICCIOTTI, G., op. cit., págs. 168-183

${ }_{34}$ Respecto de las profesiones que pudieron tener los judíos residentes en la Península en época romana y visigoda, ver GARCIA IGLESIAS, L., «Profesiones y economía familiar de los judíos españoles en la Antigüedad: Aproximación a un problema", Revista Internacional de Sociologia, n. ${ }^{\text {os }} 13-14,1975$, págs. 165-183.

${ }^{35}$ Entre los judíos de la Antigüedad no son desconocidos los casos de apostasía. Por el pasaje de Macabeos III, 1, 3, sabemos que en el siglo III a.C. un tal Dositeo abandonó su fe. 
literarias ni epigráficas al respecto, pero la duda acerca de la continuidad de esos grupos judíos en España se ha planteado de forma general. $Y$ esto inevitablemente lleva a pensar en un proceso de asimilación y de progresiva reabsorción por parte de las comunidades fenicio-púnicas, que sí gozaron de una innegable continuidad hasta entrada la época romana, como se aprecia en la documentación literaria y en la acuñación de moneda ${ }^{36}$.

Si la moderna investigación se inclina, y se trata como hemos visto de una postura lógica, por la asimilación y reabsorción, y, si posteriormente, en época romana, disponemos ya de testimonios literarios, epigráficos y arqueológicos, que prueban inequívocamente la presencia de judios en España, se crea, de esta forma, un espacio cronológico más o menos amplio, dentro del cual, en algún momento, hubo de producirse un nuevo aporte poblacional judío, del que procederían los más antiguos judíos de España. Pero cen qué momento ocurrió eso? Es opinión relativamente generalizada el situar ese supuesto aflujo - que no se asume como el único aporte de nuevos elementos poblaciones judíos- en época helenística, en que tuvo lugar un importante desarrollo de la diáspora judía hacia las tierras occidentales, con intervención muy destacada de la comunidad judía de Alejandría ${ }^{37}$. Esta ciudad ocupaba una posición geo-

Pero las apostasias de los judios no fueron muchas y, como contrapartida, se vieron abundantemente compensadas con la adquisición de muchos prosélitos. Las apostasías no fueron el mayor peligro padecido por los judíos en época helenística, sino la facilidad con que se entregaban a la imitación de las costumbres griegas de su época. Los judios, no sólo asumían nombres griegos - uno de los Sumos Sacerdotes del siglo ॥l llevará el nombre griego de Menelao-, sino que asistían a teatros y se entrenaban en gimnasios. Ver MOMIGLIANO, A., "Ebrei e Grecim, en Sesto contributo alla storia degli studi classici e del mondo antico, t. II. Roma 1980.

36 La referencia más antigua a los libiofenicios procede de Avieno (Ora Maritima, ed. A. Schulten. Barcelona 1955, pág. 1250), que los menciona a referirse al río Criso. Luego, en el siglo iv a.C., Eforo los tiene como colonos de los Cartaginenses y los sitúa antes de las Columnas. PLINIO (NH III, 19) indica que las costas meridionales, desde el Estrecho hasta Almería estaban ocupadas por gentes púnicas; ver también Estrabón, III, I, 7. PTOLomeo (II, 4, 6;9) los denomina bastulo-púnicos, mientras que Apiano, al referirse a los acontecimientos del año 155. 153 a.C., los llama blastofenicios. Con relación a esas gentes, ver PERICOT, L., Historia de España. Gran Historia General de los Pueblos Hispanos, t. I, 2." ed. Barcelona 1942, pág. 280; Thouvenot, R., Essai sur la province romaine de Bétique, reimpág. París 1973, pág. 77; TovaA, A., Iberische Landeskunde. Baetica. Baden-Baden 1974, pág. 26; González Román, C., Imperialismo y romanización en la provincia Hispania Ulterior. Granada 1981, pág. 12.

Para las acuñaciones de moneda, ver GIL FARRÉs, O., La moneda hispánica en la edad antigua. Madrid 1966; VILLARONGA, L., Las monedas hispano-cartaginesas. Barcelona 1973; ROBIN. SON, E. S. G., "Punic coins of Spain and their bearing on the Roman Republican series", Essays in Roman coinage presented to Harold Mattingly. Oxford 1956, págs. 34-53.

${ }^{37}$ Las colonias judías de Egipto gozaban de una gran antigüedad. Ya hemos aludido al caso de la comunidad judía de Elefantina. Hay otras referencias literarias, que al margen de los problemas que presentan, y de lo aleatorio de las cifras que ofrecen, parecen contener un fondo histórico. El Dt. 17,16 recuerda que reyes judíos enviaron mercenarios a Egipto. En Jr. 44,1, se 
gráfica excelente, que le permitía canalizar el comercio de las tierras del interior egipcias, a la vez que en su puerto atracaban todo tipo de naves que surcaban las aguas del Mediterráneo en todas las direcciones. Muchos miembros de la numerosísima comunidad judía de Alejandría se dedicaban a las actividades comerciales, de modo que no les podían resultar ajenos los viajes comerciales hacia las tierras del Mediterráneo occidental. Informaciones procedentes de la III Sibila, del libro de los Macabeos, de la obra de Filón de Alejandría, de los Hechos de los Apóstoles y del propio Estrabón en referencia recogida por Josefo, coinciden en destacar la abundancia numérica de los judíos por todo el mundo conocido ${ }^{38}$.

alude al asentamiento de judíos en Patros (Egipto), y Arist. 12-13 informa que Ptolomeo I deportó a Egipto a cien mil judíos, ver TSCHERIKOVER, V., Hellenistic Civilization and the Jews I. Filadelfia 1959, pág. 283. Para los judíos de Egipto y del norte de África, ver FuCHS, L., Die Juden Agyptens in ptolomâischer und rómischer Zeit. Viena 1924; DAVID, S., Race Relations in Ancient Egypt. Londres 1951; BELL, H. I., Cults and Creeds in Greco-roman Egypt. Oxford 1953; Hirschber, H. Z., A History of the Jews in North Africa, vol. I. Leiden 1974; Applebaum, S., Jews and Greeks in Ancient Cyrene. Leiden 1979.

Una de las consecuencias de la conquista de Alejandro Magno, y de la política económica seguida por sus sucesores, fue que los territorios sometidos a su dominio experimentaron un importante desarrollo económico y una gran transformación social. Así, nuevos traslados voluntarios de judios a Egipto, nuevas instalaciones de prisioneros de guerra y nuevos aportes de esclavos, aumentaron durante la época helenística el número de judios asentados en tierras egipcias. En este sentido, Alejandría, desde su fundación, contó con un contingente muy importante de judíos. FILÓN DE AlEJANDría (Flacc., 43) cifra en un millón el número de judíos, que vivían en Alejandria y en el resto de las tierras agipcias desde "Katabathmos cerca de Libia hasta las fronteras de Etiopía". A la ciudad de Alejandría venían, y desde ella partían, gentes y mercancías de todo el mundo conocido. Era, como decía Estrabón (XVII, 1,13), "el emporio más grande de la tierra habitada». La comunidad judía de Alejandría fue tan importante que algunos historiadores modernos llegan a suponer que los judíos de aquella comunidad de Alejandría gozaron de los derechos de ciudadanía plena, al igual que la tenían los griegos en esa ciudad. Pero este es algo que no está plenamente demostrado.

Con relación a la cuestión debatida de si la comunidad de Alejandría podía debatir los asuntos penales en la corte de Alejandría o debía hacerio en Jerusalén, ver GoodenOugh, E. R., "The jurisprudence of the Jewish Courts in Egypt", Lega I Administration by the Jews under the Early Roman Empire as described by Philo Judaeus. New Haven 1929, pág. 26.

Con relación al antisemitismo, que se desarrolló en Alejandría, ver Momigliano, A., "Aspetti dell'antisemitismo alessadrino in due opere de Filone", Rassegna Mensile di Israel, $n .{ }^{\circ}$ 5, 1930 , págs. 225 y ss.; SMALLWOOD, E. M., Philonis Alexandrini Legatio ad Gaium. Leiden 1970.

${ }_{38}$ Los Oráculos Sibilinos son una colección de oráculos elaborados por autores judios y cirstianos, a imitación de los "Libros Sibilinos". Los libros III-V pertenecen, con mucha probabilidad, a autores judíos. El tercero, que se atribuye a un autor judío egipcio, fue escrito hacia el 140 a.C. En este libro, en el pasaje III, 271, se dice "toda la tierra y todo el mar está llena de ti». Los Oráculos Sibilinos están editados por GAFFAKEN, J., Oracula Sibyllina. Leipzig 1912. Una edición más reciente con traducción alemana está ofrecida por E. A. Kurfess, Múnich 1951. Fragmentos del libro II y los libros III-V, con comentarios y traducción al inglés, realizados por H. C. O. Lanchester se encuentran recogidos en CharLes, R. H. (ed.), The Apocrypha and Pseudepigrapha of the Old Testament, II, 1913, págs. 368-406. En el libro Primero de los Macabeos $(15,15-23)$, se recoge la notificación, remitida a más de una veintena de reyes y de comunidades, en la que se recomienda que se dé a los judíos un trato correcto. Esto, lógicamente, hace pensar que en esos reinos y comunidades políticas había un importante sector poblacional 
Por lo que respecta a España, el libro de los Jubileos 8, 13, recoge, incorporada a un contexto más amplio, una mención concreta de Gadir, que pudiera tomarse como expresión ilustrativa de las asiduas relaciones

judio. Para este libro de los Macabeos, ver Tedesche, S. y Zeituin, S., The First Book of Maccabees. Filadelfia 1950; NANCY, J. C., A Commentary on I Maccabees. Oxford 1954; GoldSTEIN, A. J., I Maccabees. Nueva York 1976. El texto hebreo del libro Primero de los Macabeos fue escrito a finales del siglo $\|$ a.C. Por su parte A. Momigliano concreta la techa en el 129 a.C., ver "La datazione del Primo Libro dei Maccabei», en Mélanges J. Heurgon, II. Roma 1976, págs. 657-661, ahora en Sesto contributo alla stora degli studi classici del mondo antico. Roma 1980.

Por su parte, Filón de Alejandria (c. 20 a.C.-c. 50 d.C.), en varios pasajes (Leg. ad Gaium, 31; cf. Vita Mos, 2,27) dice, con manifiesta exageración, que los judios constituían la mitad del género humano. Para las obras de Filón, edición y traducción inglesa, ver Colson, F. H.; WHITAKer, G. H. y Marcus, R., Philo. Loeb, to vols. más 2 vols. suplem. Londres 1929-1962. Para las opiniones políticas de Filón, ver Goodenough, E. R., The Politics of Philo Judeaus. New Haven 1938; idem, An Introduction to Philo Judeaus. Yale 1940, Oxford 1968. Para los aspectos religiosos relacionados con este autor, ver STEIN, E., "Philo und der Midrasch", Beiheft zur ZATW, LVII, 1931.

Estrabón, en referencia recogida en FLAVIO Josefo (en Ant., 14,7.2), dice, con ocasión de la campaña de Sila contra Mitridates que el pueblo de los judíos wha llegado ya a todas las ciudades hasta el punto que no se encontraría fácilmente un lugar en la tierra habitada que no haya recibido a este pueblo y no haya sido ocupado por él». Para la edición y traducción inglesa de las obras de Josefo, ver Thackeray, H. S. J.; Marcus, R. y Feldman, L. H., "Josephus", Loeb, I-XI. Londres 1925-1965. Para algunos aspectos a los que da pie la obra de Josefo, ver BETZ, O.; HAACKER, K. y HENGEL, M., Josephus-Studien. Untersuchungen zu Josephus, dem antiken Judentum und dem Neuen Testament. Otto Michel zum 70. Geburtstag gewidment. Göttingen 1974. Para su visión de las ideas religiosas de los judíos y de la defensa que hace de las mismas, ver Guttmann, J., Die Darstellung der jüdische Religion bei Flavius Josephus. Breslau 1928; Brune, B., Flavius Josephus und seine Schriften in ihrem Verhältnis zum Jundetum... Gütersloh 1913.

En los Hechos de los Apóstoles - cuya fecha de redacción se discute, aunque varios investigadores sitúan entre el 90 y $95-$ - en el pasaje $2.5,9.11$, se señala que cresidian en Jerusalén judíos varones piadosos de cuantas naciones hay bajo el sol». Y en 15.21: «Pues Moisés desde antiguo tiene en cada ciudad quienes lo expliquen leyéndolo en las sinagogas todos los soldados". Para la composición y fecha de esa obra, ver Torner, C. C., "The Compossition and Date of Acts", Harvard Theological Studies, 1, 1916. Para una visión general de la obra, EHRHARDT, A., The Acts of the Apostles. Manchester 1969.

Para algunas de estas citas literarias recogidas en esta nota, ver ReINaCH, Th., Textes d'auteurs grecs et romains relatifs au judaisme. París 1895 , textos n. ${ }^{\text {os }} 51$ y 145; SIMON, H., "Verus Israel...", op. cit., pág. 52.

Todas estas informaciones, despojadas como es pertinente de su enfática exageración, son un claro indicativo del elevadísimo número de judios que se encontraban diseminados por la tierra habitada. Los cálculos generales realizados -en los que se excluyen los judíos residentes en Palestina- eleva entre cuatro y seis millones el número de judíos de la diáspora. Para estas generales y poco fiables estadisticas, ver JUSTER, J., Les Juifs dans I'Empire Romain. París 1914, 1. págs. 179-209 que aceptó las cifras proporcionadas por BarHebraeus, un escritor cristiano de origen judío del siglo xIII. Valora estas cifras y las opiniones de BARON, Juster S. W., A Social and Religious History of the Jews, I, 2. ${ }^{a}$ ed. Nueva York 1952, págs. 170 y 370-372; HarnaCK, A. v., Die Mission und Ausbreitung des Christentums in den ersten drei Jahrhunderten I. Leipzig 1923, págs. 2 y ss. Simon, H., Verus Israel. Etude sur les relations entre chretiens et juifs dans l'émpire romain. Paris 1948, págs. 54-55; TSCHERIKOVER, V., Hellenistic Civilization and the Jews 1. Filadelfia 1959, págs. 292-295; STERN, M., “The Jewish Diaspora” en S. Safrai y M. Stern (eds.), "The Jewish People...», op. cit., I, 1, págs. 117 y ss. 
comerciales entre Oriente y Occidente, si no fuera por los problemas que todavía ofrece esta obra respecto a la fecha de su redacción ${ }^{39}$. En el libro primero de los Macabeos 8, 3, se cuenta como Judas Macabeo estaba en conocimiento de que los romanos con sus conquistas peninsulares se habían apoderado de las minas de oro y plata, información que pudo muy bien haberla transmitido cualquier comerciante viajero, y quién mejor en este sentido, aunque no sepamos nada al respecto, que un comerciante judío procedente de España ${ }^{40}$. En la epístola a los Romanos XV, 24-28, San Pablo expresa su intención de venir a España ${ }^{41}$, lo que, de acuerdo con su habitual modo de proceder, podría deberse a la existencia de comunidades judias ${ }^{42}$ en nuestro territorio, porque, a pesar de ser considerado San Pablo como el apóstol de los gentiles, no era infrecuente

39 El libro era conocido por la traducción etíope de la versión latina y siríaca. Del original hebreo sólo se tienen algunos fragmentos, que fueron encontrados en Qumran. Este libro, entre los miembros de la comunidad de Qumran, debió de gozar de gran popularidad, hasta el punto de que hay quien piensa que se trata de un trabajo realizado por un miembro de esa comunidad. La fecha de redacción, discutible, se acostumbra a situar entre c. 140 hasta c. el 100 a.C. Para la edición de esta obra, ChaRLES, R. H. (ed.). The Apocrypha and Pseudepigrapha of the Old Testament in English 11, 1913, págs. 1-82. Para la dimensión escatológica de esa obra ver DAVENPORT, G. L., The Eschatology of the Book of Jubilees. Leiden 1971. La mención a Cadir contenida en el libro de los Jubileos 8,13 , la toma $\mathrm{KoCH}_{1}$ M., (“Zum frühen Jüdische...», op. cit., pág. 233), bien es cierto que sin mucho convencimiento, como un indicativo de las relaciones comerciales entre Oriente y Occidente.

${ }^{40} \mathrm{KoCH}$, M., “Zur frühen Jüdischen...», op.it., pág. 233, nota 25 , apenas da importancia como indicativo de esas relaciones a ese pasaje contenido en el libro primero de los Macabeos. Por el contrario, Garcia IGlesias, L., "Los judíos de la España antigua...", op. cit., pág. 41, lo valora positivamente y considera que la noticia le pudo ser transmitida a Judas Macabeo por judios españoles o romanos.

${ }^{41}$ La posible llegada de San Pablo a la Península lbérica ha sido objeto de discusión. Pero que haya venido o no, resulta una cuestión secundaria respecto a la suposición de la posible existencia de comunidades judías en la misma. En este sentido, el dato importante lo otorga la propia manifestación de San Pablo de querer venir a la Península. Sobre esta controvertida venida, ver GARCí VILLADA, Z., Historia eclesiástica de España, t. I. Madrid 1929, págs. 105-145; VEGA, A. C., "La venida de San Pablo a España y los Varones Apostólicos", BRAH, n. "154, 1964, págs. 7 y ss.; DiAZ y Diaz, M. C., "En torno a los origenes del cristianismo hispano", en Las Raíces de España. Madrid 1967, págs. 423 y ss.

42 Las palabras de San Pablo vertidas en la Carta a los Romanos 1,16 «no me avergüenzo del Evangelio que es poder de Dios para la salud de todo el que cree, del judío primero, pero también del griego", dan a entender que se realizaba una práctica de adoctrinamiento, primero en ámbitos judíos y luego de los gentiles. Por ello, algunos investigadores modernos piensan que el pasaje que recoge la intención de San Pablo por venir a España, hace pensar, implícjtamente, en la existencia de comunidades cristianas en la Península lbérica. Son de esta opinión Williams, A. L., Adversus ludaeos. A bird'seye view of christian "Apologie» until the Renaissance. Cambridge 1935, págs. 208-209; STERN, M., "The Jewish Diaspora" en S. Safrai y S. Stern (eds.), "The Jewish People...", op. cit., págs. 169-170; García Iglesias, L., "Los judios...", op. cit., pág. 354; KoCH, M., "Zur frühen...", op. cit., pág. 236. DiAZ Y DiAZ, M. C., "En torno a los orígenes...". op. cit., pág. 429, cuando se plantea la cuestión del viaje de San Pablo a la Península, opina que "comunidades judías, que existieron sin duda, pero sobre cuyo número, densidad y localización carecemos de datos, pues en ellas era donde se realizaba siempre la primera siembra". 
que el adoctrinamiento religioso lo iniciase con los judios. Tampoco, aunque no se disponga de la pertinente información, hay que cerrar sin más las puertas a la posibilidad de que como consecuencia de las esporádicas tensiones y presiones sufridas por los judios de Roma, algunos de ellos buscasen acomodo en Hispania ${ }^{43}$. Hay fuentes, indudablemente, que ofrecen datos, a través de los cuales se percibe que los judios tienen un mejor conocimiento de la parte oriental del Mediterráneo que de las occidentales; ello no es óbice, sin embargo, para que las fuentes hebraicas posbiblicas, las talmúdicas, ofrezcan noticias referentes a las tierras hispanas $^{44}$.

\section{TESTIMONIOS LITERARIOS, EPIGRÁFICOS Y ARQUEOLÓGICOS}

En época romana dejamos ya de movernos en un terreno de las lucubraciones, por muy verosímiles que resulten, para entrar en el de los

${ }^{43}$ A Roma llegaban procedentes de diversos puertos del Mediterráneo grandes cantidades de suministros destinados a aplacar el enorme estómago de esa ciudad. $Y$ no hay que perder de vista que si no en trigo, sí en aceite, la Bética era una de las principales abastecedoras. Las necesarias actividades comerciales y artesanales arrastraban hacia Roma a muchas personas, entre ellas a los judíos. El desempeño de este tipo de actividades facilitaba la salida y el hallazgo de trabajo en otros lugares, cuando en el lugar de residencia anterior se habían desencadenado acciones represivas. Algo que ocurrió en algunas ocasiones con los judíos de Roma. Así, bajo Tiberio, en el 19 d.C., algunos judíos hurtaron los regalos que la matrona Fulvia habia entregado con destino al Templo de Jerusalén, los judíos de Roma fueron expulsados de Roma, privándoseles de sus privilegios (Josefo, Ant. XVIII, 3, 5; TÁcito, Ann., II,85; Suetonio, Tiber., 36). Poco tiempo después, dichos judíos pudieron regresar a Roma y recuperar sus privilegios. También en tiempos de Claudio, entre el 49 y 50 , se decretó la expulsión de los judíos de Roma, aunque, o no se aplicó, o dicha expulsión adquirió una forma muy suave (DIÓN CASIO, LX, 6). Por otra parte, no faltaron ocasiones en las que los judios de Palestina acudieron a la sublevación contra los romanos. No parece, no obstante, que dichas sublevaciones afectasen a la colonia judía de Roma y a las comunidades judias del resto del imperio.

${ }_{44}$ Los escritos talmúdicos - que tienen redacciones posteriores, que pudieran corresponder quizá al siglo ıv d.C., pero conteniendo noticias que se remontan a momentos anteriores-registran noticias alusivas a España. Entre éstas se encuentran, por un lado, las que dicen que. tras la toma del Templo de Jerusalén en el 70, los tapiceros del Templo se encaminaron hacia España, por otro, las que aluden a exportaciones españolas de salazones de pescado con destino a Palestina, motivando, en razón a la distancia, que se ampliara de uno a tres años la prescripción de la propiedad. Para el conocimiento geográfico que ofrecen estos estudios talmúdicos, ver AvI-YONAH, M., "Geschichte der Juden im Zeitalter des Talmud", Studia ludaica, II. Berlín 1962, pág. 175; KоCH, M., “Zur frühen jüdischen...», op. cit., pág. 242. Para la noticia referente a los tapiceros del Templo, ver APPLEBAUM, S., "The organization of the Jewish Communities in the Diaspora", en S. Safrai y M. Stern (eds.), "The Jewish People...", op. cit., I, pág. 482, II, pág. 723, respectivamente; GarCia IGLESIAS, L., "Los judíos en la España...", op. cit., pág. 47. Para las exportaciones de salazones de pescado y la ampliación a tres años para la adquisición definitiva del derecho de propiedad "afin de donner les délais nécessaires aux parties résidant en Espagne", ver THOUVENOT, R., Essai sur la province romaine de la Bètique, 2. ${ }^{\text {a }}$ ed. París 1973, pág. 187; Applebaum, S., "Economic life in Palestine", en S. Safrai y M. Stern (eds.), "The Jewish People...", op. cit., II, pág. 670. 
datos. Pero no toda información de época romana corresponde a una misma etapa. Así, las noticias literarias referentes a los judíos peninsulares pertenecen a la época bajoimperial. La información literaria emana de varias fuentes documentales. Una de ellas son las Actas del Concilio de Elvira ${ }^{45}$, algunas de cuyas disposiciones tratan de erradicar prácticas, en las que se ven implicados cristianos y judíos, mientras otras se suponen inspiradas en tradiciones judías. La segunda fuente documental se encuentra en la crítica acerada de San Gregorio de Elbira ${ }^{46}$ contra la observancia judía del sábado y la práctica de la circuncisión, y contra la precipitada e inconsciente inclinación de los cristianos a «judaizar» ${ }^{47}$. Ese

45 Son las actas más antiguas que se conservan. Algún investigador, por discrepancias de indole interna y externa, así MEIGNE, M. ("Concile ou collection d'Eivire?", Rev. Hist. Eccl., n." 70, 1975, págs. 361-387), consideran que algunos de los cánones que aparecen en las Actas (VIVES, J., Concilios visigóticos e hispano-romanos. Barcelona-Madrid 1963) no pertenecerian realmente a dicho concilio. Dichas dificultades existen, pero a lo sumo pueden ser exponente de los problemas que ofrecen las actas. Uno de estos problemas está relacionado con la fecha. Las Actas sólo aluden al día en que el concilio se celebró. Son las valoraciones que se han hecho sobre el contenido de alguno de los cánones lo que ha inclinado a algunos autores a proponer diversas fechas. Las situadas entre el 295-300 y en torno al 306 son las que parecen más probables. De la primera es partidario HaRnack, A. v., Die Chronologie der Altchristlichen Litteratur II. Leipzig 1904, págs. 451-452. Hacia la segunda, la del 306 d.C., se inclina GARCiA VILLADA, Z., “Historia eclesiástica...”, op. cit., pág. 302.

En las Actas del Concilio de Elvira aparecen algunos cánones cuyo contenido disciplinar parece que tiene como misión impedir las relaciones entre judios y cristianos. Entre estos cánones se encuentra el 16, que trata de evitar el matrimonio de jóvenes cristianas con judíos; el 49, que prohíbe el que los judíos bendigan los campos de los cristianos; el 50, que condena los banquetes conjuntos entre judíos y cristianos; y el 78 , que, en una implicación social más amplia, prohibe a los cristianos aduiterar con mujeres judías. Estas disposiciones canónicas hacen sospechar no sólo la existencia de importantes y no pocas comunidades judías en la Península, sino que incluso miembros de esas comunidades judias tenian un trato frecuente e una importante ascendencia sobre los cristianos. Para la valoración e interpretación de estos cánones, ver Lombardia, P. "Los matrimonios mixtos en el Concilio de Elvira", $A H D E, n .{ }^{\circ} 24$, 1954, págs. 5550-5554; Garcia IgLESIAS, L., "Los cánones del Concilio de Elbira y los judíos", El Olivo, n. ${ }^{05}$ 33-34, 1977, págs. 61-70; SOTOMAYOR, M., Historia de la lglesía en España. I. La Iglesia en la España romana y visigoda (siglos I-VIII). Madrid 1979, págs. 82-119.

Hay en las Actas del Concilio de Elvira otros cánones -26, 36 y 63--, que sin hacer mención expresa a judios, se considera que han podido estar inspirados en prácticas judias, ver al respecto, Blumenktanz, B., Juifs et chrétiens dans le monde occidental, 430-1096. París-La Haya 1960 , págs. 106 y 285 . Así, el canon 26 exige a los cristianos ayunar el sábado; el 36 prohíbe la existencia de pinturas en las iglesias y el 61 busca impedir que el viudo contraiga matrimonio con la hermana de su mujer difunta. Por lo que hace al canon 36, ver LENAIN, D., "Le canon 36 du concile d'Elvirem, Rev. Hist. Litt. Rel., n. ${ }^{\circ}$ 6, 1901, págs. 458-460.

${ }_{46}$ Entre los trabajos referentes a San Gregorio de Elvira se encuentran los de MAzORRA Abascal, E., Gregorio de Elvira. Granada 1967; Collantes Lozano, J., San Gregorio de Elvira. Estudio sobre su eclesiología. Granada 1954; BUCKELEY, F. J., Christ and the Church acoording the Gregory of Elvira. Roma 1964; SimonetTI, M., Gregorio de Elvira. La fede. Turin 1975. Para más referencias bibliográficas con relación a otras cuestiones de la obra de San Gregorio de Elvira, ver SotomayoR, M., «Historia...", op. cit., págs. 188-189.

${ }_{47}$ En el 1900 , P. Batiffol y Wilmart reunieron una veintena de homilias, que atribuyeron equivocadamente a Origenes. De ahí el nombre de Tractatus Origenis con el que se la conoce. 
autor no es un personaje cualquiera. Nacido en fecha desconocida en la misma ciudad en la que se celebró el concilio y muerto después del 392 , es uno de los más duros oponentes del arrianismo, que apoyó a Lucifer de Cagliari en su negativa a conceder el perdón a aquellos que había "arrianizado». Las palabras de San Gregorio de Elbira, escritas con posterioridad a la reunión del concilio de Elbira, no sólo vienen a corroborar una vez más la existencia de comunidades judías, sino que implícitamente ponen de manifiesto que la convivencia entre las comunidades cristianas y judías era amigable, lo que propiciaba que los judíos practicasen el proselitismo entre algunos cristianos predispuestos a judaizar. Otro documento, la reiteradamente citada carta del obispo Severo de Menorca, narra una serie de acontecimientos vividos por la comunidad judía de Mahón en el siglo $v^{48}$. Pero se trata de una carta y de un commonitorium, cuya autenticidad en el siglo $\vee$ ponen en duda Blumenkranz y Díaz y Díaz, considerándola como una falsificación del siglo vil; ${ }^{49}$ la Altercatio Ecclesiae et Synagogae ${ }^{50}$ ha sido considerada por algunos como el commonitorium de Severo.

Son, pues, las inscripciones las que nos remiten a época romana más temprana. En el Museo de Ibiza hay un ánfora con marca, cuya datación se sitúa en el siglo $1^{51}$, que ha dado pie a algunas consideraciones sub-

El mismo A. Wilmart señaló, posteriormente, que no eran obra de Orígenes (Bull. de Litt. Ecles., 1906, págs. 233 y ss.). Las referenclas recogidas en nuestro texto corresponden a Tract. Origenis, III, IV y VIII. Sobre esos ataques a las prácticas judías, ver ThOuvenOt, R., "Chrétiens et juives à Grénade au IV ème siècle après J.C.", Hesperis, n. ${ }^{\circ} 30,1943$, págs. 206-211. A este respecto hay que tener presente que, partiendo del hecho de que, dentro de una obra que comprende una veintena de homilias, las críticas a las practicas judias y los ataques a la tendencia de algunos cristianos a judaizar, no son numerosas. Por esa razón algún autor ha pensado que dichas referencias tenían por finalidad dotar a los lectores de argumentos a utilizar en las controversias ideológicas. Ver al respecto, Blumenkranz, B., "Altercatio Ecclesiae contra Synagogam", Revue du Moyen Age Latin, n. ${ }^{\circ}$ 10, 1954, pág. 13, nota 14

${ }_{48}$ Sobre esta carta, ver SEgUi VIDAL, G., La carta encíclica del obispo Severo. Estudio crítico de su autenticidad e integridad con un bosquejo histórico del cristianismo balear anterior al siglo VIII. Palma de Mallorca 1937. Para los hechos narrados en esta carta, ver SerRA, M. L.; GRo. selló, G. y Orfila, J. A., Historia de Menorca. I. De los orígenes al tinal de la Edad Media. Mahón 1977, págs. 95 y ss.; Garcia IGLESIAS, L., "Los jứíos de la España...", op. cit., págs. 87 y ss.

49 Lo consideran creación posterior, BlumenKRAN Z, B., Les auteurs chrétiens latins du Moyen Age sur les juifs et le Judaisme. París-La Haya 1963, pág. 34, nota 218; DiAz y DiAz, M. C., "De patrística española", Revista española de Teología, n. ${ }^{17}$, 1957, págs. 11-12.

${ }_{50}$ Sobre la Altercatio, ver SEgUI VIDAL, G. y HILLGARTH, J. N., "La Altercatio y la basílica paleocristiana de Son Bou de Menorca», Boletín de la Sociedad Arqueológica Luliana, n. 31 , 1954.

51 SOlÁ SOLÉ, J. M., "De epigrafía”, Sefarad, n. ${ }^{\circ} 20,1960$, págs. 291-294, para situar cronológicamente esta inscripción, toma la fecha que se concede a ejemplares mejor conocidos cronológicamente y con los que el ánfora en cuestión presenta semejanzas estilísticas. Por otra parte, este autor toma la pieza, bien como exponente de la existencia de una comunidad judía, bien como indicio de un comercio. 
sidiarias. Quien ha estudiado la pieza en su aspecto epigráfico, con la ayuda de paralelos de ánforas encontradas en Samaria, considera que la marca de este ánfora, frente a opiniones anteriores que la consideraban como una marca púnica, es hebraica; y, en consecuencia, apunta la posibilidad de la existencia "desde lejana época" ${ }^{52}$ de una comunidad judía en Ibiza, de la que procedería o bien el alfarero, o bien el propietario, o bien el fabricante del producto destinado a ese receptáculo - sin cerrar las puertas a la posibilidad de que el ánfora procediese de Palestina como exponente de una actividad comercial ${ }^{53}$, que no tiene por qué relacionarse con la existencia de un comercio directo entre Palestina e Ibiza.

De la media docena de inscripciones judías de la Hispania romana, sólo algunas podemos considerarlas como indiscutiblemente judías, bien por la indicación del lugar de procedencia del personaje, bien porque entre los términos utilizados para su denominación aparezca el término inequívoco de ludaeus/a, o bien porque en los epígrafes en cuestión se encuentre algún elemento lexical o figurativo asociado frecuentemente a los judíos. En el resto de las inscripciones consideradas como correspondientes a judíos se llega a tal conclusión a través de ingeniosos criterios onomásticos, y mediante comparaciones oportunas de la onomástica considerada como judía en otros lugares extrapeninsulares.

De Mérida procede una inscripción ${ }^{54}$ - cuya datación se piensa que pudiera situarse posiblemente en el siglo॥-, en la que se documenta un lustinus Menandri filius Flavius Neapolitanus, es decir, un personaje foráneo ${ }^{55}$, que se asentó en Mérida y que era originario de la ciudad de

52 КосH, M., “Zur frühen jüdischen...", op. cit., pág. 237, nota 33, considera que la expresión utilizada por J. M. Solá Solé «desde lejana época" resulta demasiado general y no especifica el momento hasta el que podría remontarse dicha posible comunidad judia. Por otra parte, le resulta difícil admitir que una sola ánfora sea un elemento de entidad suficiente como para valorar la continuidad de una población judia, que habria que remontar a época lejana. No obstante, cree, subsidiariamente, que dicha ánfora abre el camino a la posibilidad de que en el siglo I existiese un taller judío en la isla.

53 BOWERS, W. P., "Jewish communities in Spain in the Time of Paul the Apostle", Journal of Theological Studies, $n .{ }^{\circ} 26,1975$, pág. 400 , considera que esta ánfora marcada es indicio de una actividad comercial. Por su parte, García IGLESIAS, L., “Los judíos...», op. cit., pág. 51, piensa que ambas posibilidades no son excluyentes.

${ }_{54}$ CIL II, 515: lustinus. Menandri. f(ilius). Ter./ Flavius. Neapolitanus. anno/ XLVI. h(ic) s(itus) e(st) $s$ (it) t(ibi) t(erra) l(evis). Sabina. marit(o)/ optimo. et. merentissimo. et/ Menander. filius. cum. seroribus/ suis rece(pta). et. Salvina/ patri. piissimo. Tal y como aparece en E. Hübrier, la recoge VIVES, J., Inscripcione s latinas de la España romana. Barcelona 1971, n. ${ }^{\circ} 3455$. GaAcía IGLESIAS, L., "Los judíos en la España...", op. cit., pág. 34, doc. III, en la primera línea completa la palabra filius, haciendo desaparecer la secuencia Ter., que leia Hübner y seguía J. Vives.

${ }_{55}$ Ver ALBERTIN1, E., "Les étrangers résident en Espagne à l'epoque romaine», en Mélanges Cagnat. París 1912, pág. 302; GARCIA Y BELLIDO, A., "El elemento forastero en España romana", BRAH, n. ${ }^{\circ} 144,1955$, págs. 142-143; GARCía IGLESIAS, L., "Judíos en la Mérida romana y visigoda", Revista Estudios Extremeños, n. ${ }^{\circ} 32,1976$, pág. 81 
Flavia Neápolis ${ }^{56}$, fundada por Vespasiano para compensar la lealtad manifestada por la clase media griega de las ciudades del entorno, con cuya población realizó nuevos asentamientos ${ }^{57}$. De no haber señalado el epigrafe la patria del personaje, nunca hubiéramos sabido que se trataba de alguien originario de tierras samaritanas. lustinus -cuyo nombre al igual que el de Recepta y Salvina pudieran ser traducciones de nombres originales hebraicos-, no es ciudadano romano, puesto que figura con tan sólo su nombre personal. No es, por tanto, descendiente de aquellas familias, griegas o no, con las que se hizo la deductio de la colonia Neapolis quae antea Hamortha dicebatur. Ignoramos si se trataba de un esclavo, lo mismo que los miembros de su familia, o de un peregrino, pero entre estas dos posibilidades parece estar la solución.

Otras dos inscripciones tienen en el aspecto que consideramos el interés sin igual de que ambas aluden a la naturaleza judía de los difuntos. Una de ellas la conocemos por el manuscrito de A. Rodríguez Moñino ${ }^{58}$. La lápida, de acuerdo con la información proporcionada, procedía de Villamesías (Cáceres), es decir, un lugar situado hacia el interior, en una zona rural que, en principio, poco tiene que ver con los lugares costeros y con las grandes urbes comerciales en las que acostumbraban a asentarse los judíos. Pero, como hemos puesto de manifiesto en otro lugar, la discrepancia es aparante, ya que es muy probable que el territorio, de Villamesías perteneciese a la colonia de Emerita Augusta ${ }^{59}$. La inscripción,

56 Justin., Apol., I. 1; Eusebio, Hist. eccl., 4. 12; Plinio, NH, n. ${ }^{\circ}$ 5. 13,69.

57 Ver al respecto, Grant, M., The Jews in the Roman World. Londres 1973, pág. 204.

${ }_{58}$ El manuscrito de A. Rodríguez Moñino, facilitado por A. Gómez Moreno, fol. 8, recoge esta inscripción en la forma en la que se ofrece en Hisp. Ant. Epig., 4-5, 1953-1954, pág. 23 , n. ${ }^{\circ} 752$ Alucius/ Roscius. C. L./ H.S.E./ ludeus/Acoli. C. S.

59 Es conocido que el territorio de la colonia Augusta Emerita era muy extenso, discontinuo y que al mismo pertenecían algunas prefecturas. Para establecer los límites territoriales de la colonia Augusta Emerita y los de Norba Caesarina, el criterio más usual es aquél que toma en consideración las inscripciones procedentes de aquellas tierras y que contienen la mención de la tribu. Se sabe que los integrantes de la colonia Norbense se adscribian a la tribu Sergia, mientras que los de Augusta Emerita lo hacian en la Papiria. Inscripciones con mención de esas tribus procedentes de tierras próximas a esas dos colonias dan pie a pensar, razonablemente, que el lugar en cuestión correspondería a una u otra colonia. Al hilo de esta consideración, hay que tener presente que, por inscripciones procedentes de la localidad de Villamejías - situada en el camino que llevaba a la Praefectura Turgeliensis-, se percibe que los habitantes de esa zona se adscribian a la tribu Papiria, la misma a la que se incorporaban los miembros de la colonia emeritense. Es muy probable que el límite entre ambas colonias pasase por allí.

Para los aspectos jurídicos de las comunidades lusitanas, ver LóPEZ MELERO, R., "El territorio de Lusitania en sus aspectos jurídicos", en Actas de las II Jornadas de Metodologia y Didáctica de la Historia (Historia Antigua). Cáceres 1984, págs. 75-86. Para las delimitaciones territoriales entre ambos territorios ver SAYAS ABENGOCHEA, J. J., "El caso de Norba Caesarina y sus contributa Castra Servilia y Castra Caecilia", Mélanges de la Casa de Velázquez, n. ${ }^{\circ} 21$, 1985, págs. 61-75. Sobre la tribu Papiria en la zona, ver FoRNI, G., "La tribu Papiria di Agustua Emerica", en Actas del Bimilenario de Mérica. Madrid 1976, págs. 33-42; SÁnchez ABAL, J. L. y Redondo, 
tal y como nos ha llegado a través del manuscrito, presenta algunas dificultades, entre ellas la forma ludeus, monoptongación poco frecuente de ludaeus, que es, sin embargo, de tono menor. Más problemático resulta el asumir que ese término funcione como antropónimo. El desarrollo que de esta inscripción hace, con criterios muy personales, R. Hurtado de San Antonio, muestra las dificultades que suscita ${ }^{60}$. En cualquier caso, la inscripción parece moverse dentro de un marco social de esclavos y libertos.

La otra inscripción, posiblemente del siglo III, procedente de Adra, corresponde a una difunta considerada por A. García y Bellido como esclava, pero que parece tratarse más bien de una liberta, de la que se especifica su condición étnico-religiosa de ludaea. El nombre gentilicio de (An)nia, muy en consonancia con el hebro Anna, se encuentra reforzado por el cognomen Salo(mo)nula, formado así en razón de la etnia de la persona en cuestión ${ }^{61}$.

De Tarragona proceden otros dos documentos epigráficos que sin datos decisivos se sitúan en el siglo Iv. Una de ellas es una inscripción funeraria en griego dedicada a un personaje denominado Nectaris, egipcio

J. A., «La tribu Papiria: testimonio de la colonia Emerita Augusta en la Alta Extremadura", Boletín del Museo Arqueológico Nacional, $n .^{\circ} 3,1985$, págs. 61-68.

so Huartado de SAN Antonio, R., Corpus provincial de Inscripciones latinas de Cáceres. Cáceres 1977 , págs. $331, n .{ }^{\circ} 773$, parece que con excesiva audacia, completa e interpreta la inscripción de la forma siguiente: Alucius/Roscius $C$ (aii) l(ibertus)/ $h$ (ic) s(itus) e(st)/ ludeus/ Acoli(tus) C(aii) s(ervus). ¿Quizá Acili(ius) en lugar a Acoli(tus)? El texto, de cualquier forma, tal y como nos ha sido transmitido, resulta bastante sospechoso por lo que, a falta de datos más determinativos, completar e interpretar la secuencia de la inscripción, resulta muy arriesgada. $\mathrm{KOCH}, \mathrm{M}$., «Zur frühen jüdischen...», op. cit., pág. 254, no otorga ningún valor a este testimonio y lo considera como muy sospechoso. Lo mismo hace SoLIN, H., «Juden und Syrer im westlichen Teil der römischen Welt. Eine ethnisch-demographische Studie mit besonderer Berücksichtigung der sprachlichen Zustände», ANRW 11.29.2. Berlín-Nueva York 1983, pág. 750. Es cierto que el desarrollo que se hace de algunas de las abreviaciones de la inscripción resulta inseguro y problemático. No obstante, la inscripción parece remitir a un ambiente social de esclavos y libertos. Y la compra y venta de esclavos, su trasiego de un lugar a otro, ha sido uno de los medios más importantes para contar con la presencia en tierras occidentales de gentes procedentes de las regiones del Mediterráneo oriental. El trabajo de M. Bang, centrado en Roma, es significativo al respecto, BANG, M., "Die Herkunft der römischen Sklaven", Mitteilungen des K. D. Archaeologischen Instituts, ${ }^{\circ}{ }^{2} 25,1910$, págs. 223-251.

${ }_{61}$ ClL II, 1982: (An) nia Salo (mo) nula an(norum) // men(sum) III die(rum) // ludaea. El nombre de (An) nia pudiera ser también, aunque más improbable (li) nia o (Lici) nia. Hübner pensa también que el cognomen Salo (mo) nula podría construirse como Salo (ni) nula. FITA, F., "Epígrafes romanos de la ciudad de Adra", BRAH, n. 70,1917 , págs. 142-144; DiEHL, E., Inscriptiones latinae christianae veteres. Leipzig 1925-1931, n. ${ }^{\circ} 4920 ; \mathrm{FREY}$, J. B., Corpus inscriptionum iudaicorum, I. Ciudad del Vaticano 1936, pág. 477; A. Ferrua en VIVES, J., Inscripciones cristianas de la España romana y visigoda. Barcelona 1969, pág. 144, n. ${ }^{\circ} 429$; CANTERA, F. y MiLlas, J. M., Las inscripciones hebraicas de España. Madrid 1956, n. 283; GaRCia IGLESIAS, L., "Los judios...", op. cit., pág. 35 de la separata, doc. V; BLÁZQUEZ, J. M., "Relaciones entre Hispania y los semitas...", op. cit., pág. 642. 
de origen, puesto que procede de la ciudad de Pitermon ${ }^{62}$. Es, por tanto, un exponente de la comunidad extranjera asentada en Tarragona, en donde, por otras informaciones, incluidas las epigráficas, sabemos que existía una comunidad judía. No es improbable, por tanto, que dicho egipcio fuese judío ${ }^{63}$.

La otra inscripción es innegablemente judía. Se trata de un epígrafe bilingüe greco-latino, que se suele datar en el siglo $v$, y que se refiere a un personaje denominado Lasies en latín y Latoues en griego, sin que se encuentre una explicación satisfactoria para tal discrepancia. El dedicante, originario de Cícico (Propóntide), era nieto de Rab Latoues y archisinagogo de la comunidad judía de Tarragona. Quien redactó los textos de esta inscripción bilingüe se movía mejor, a lo que parece, en la lengua griega que en la latina, lo que le hace apuntar a J. M. Millás, uno de los editores de esta inscripción ${ }^{64}$, la probabilidad de que el ambiente en el

62 De la necrópolis paleocristiana de Tarragona procede una inscripción griega, situada cronológicamente en el siglo iv o en el $v$, que menciona a Nectaris, personaje de procedencia egipcia. La inscripción fue editada por vez primera por BELTRÁN, P., “Excavaciones de la necrópolis romano-cristiana de Tarragona», Memorias de la Junta Superior de Excavaciones, $\mathrm{n} .^{\circ} 88$. Madrid 1927, pág. 15, cuya lectura es seguida por BATLE HugUET, P., «Les inscripcions paganes de la necropolis romano-cristiana de Tarragona», Anuari d. I'Institut d'Estudis Catalans, $n .^{\circ} 8$, 1936. Fue Olives Canals, $S$., "La inscripción griega $n .{ }^{\circ} 103$ del Museo paleocristiano de Tarragona", Bol. Arqu. de la Real Sociedad Arqu. de Tarragona, n. ${ }^{\circ} 46,1946$, págs. 41-46, quien realizó un nuevo estudio de la inscripción, ofreciendo una nueva lectura: enthade kat(a)/ Nekta/ ris Taletes/chorio piter/mon. Este autor fue quien estableció la procedencia egipcia del personaje, en lo que es seguido, al igual que en su lectura, por otros autores, García IGLESIAS, L., "Los judios...", op. cit., pág. 35 de la separata, doc. VII.

${ }_{63}$ La inscripción es innegable testimonio de la comunidad foránea, que se asentó en Tarragona. Una comunidad que pudo ir in crescendo, y que estaría dedicada, muy probablemente, a las actividades comerciales, que, a la altura del Bajo Imperio, parece que fueron muy activas y dinámicas en Tarragona. De esa misma capital procede otra inscripción, quizá coetánea, que está relacionada, inequivocamente, con judios. Apoyándose en los datos de esta segunda inscripción, se ha pensado que el egipcio al que hace referencia a inscripción mencionada en primer lugar, fuese, quizá, un judío. Fue MILLÁS, J. M., «Una nueva inscripción bilingüe de Tarragona", Sefarad, n. ${ }^{17}, 1957$, pág. 10, el que lanzó la propuesta de que Nectaris pudiera ser un judío.

64 Dió a conocer esta inscripción SÁnCHEz LeAL, J., “Hallazgos recientes", Bol. Arqu. de la Real Sociedad Arqu. Tarragona, $n .^{\circ}$ 52, págs. 425-426. El texto ofrecido por Millas VALLICROSA, J. M., “Una nueva inscripción judaica bilingüe en Tarragona», Sefarad, n. ${ }^{\circ} 17,1957$, págs. 3 y ss., es el seguido por los diversos autores: in nomine domi /ni requiesci t in is/ ta inquisio ne Rab/Lasies. s. ne pos? / didascali r equies /cit cum pac e / entha katak(eitai)/ Rab Latoue(s pa)/ ra tou mak(aris)/ tou Ku? (=)/ archesyn(agogou)/ Kypseke(nos)/ dekeo(s)/ geane(a)/ neu Lo(bes)/ kyree/ tethne. García IGLESIAS, L., "Los judios de España...", op. cit., pág. 35 de la separata, doc. VI; BLAzZuEZ, J. M., "Las relaciones entre Hispania y los semitas...", op. cit., pág. 640. AlföldY, G., "Die römischeen Inschriften von Tarraco", Madrider Forschungen, n. 110. Berlín 1975, pág. 1075, recogiendo la bibliografía anterior: In nomine $D$ eei perpet? ui requiesci $t$... ta inq. Visigo $t$... Lasies soce $r$ Didascali iacit cum pac $e$. entha katak eitai rab Latoust ... ratoumak ... neulo ... kureet ... tethnek e ... A partir del dato, no decisivo, de la fórmula hic requiescit, que VIVES, J. («Inscripciones cristianas...", op. cit., pág. 60) opina que hay que situar 
que se desenvuelve el autor sea el judaico-oriental, que, por indicios de bastante fuste, parece haber sido una de las bases étnico-geográficas sobre las que se conformó la comunidad judía de Tarragona.

De la Alcudia de Elche proceden tres inscripciones en mosaico del pavimento de un edificio que parece remontarse al siglo iv ${ }^{65}$. Fue E. Albertini ${ }^{66}$, que había participado en la excavación del edificio, quien, basándose en la interpretación y valoración de los epígrafes pr (os) euché lao... (término utilizado para designar la sinagoga) y ... archotón ke presbiteron, concluyó que se trataba de una sinagoga: la más antigua de la que se tenía noticia en la Península, pues se remonta al siglo Iv, si atendemos al criterio estilista de los mosaicos. Y como sinagoga la han aceptado mayoritariamente los investigadores ${ }^{67}$, lo cual no implica que no haya habido voces discrepantes, y no de pequeña entidad, como la de $H$.

con posterioridad al 450 , no hay que cerrar el camino a la posibilidad de que la inscripción corresponda al siglo $v$.

65 La excavación de ese edificio fue iniciada conjuntamente por Ibarra, P., y por Albertini, E., quienes publicaron separadamente los resultados y valoraciones. IBARRA, $P$., "Antigua basílica de Elche", BRAH, n. ${ }^{\circ} 49,1906$, págs. $119-132$, considera que ese monumento era una basilica.

66 Albertini, E., "Rapport sommaire sur les fouilles d'Elche (Espagne)», Comptes rendues de l'Acad. des Inscript. et Bell. Lettres, 1905, págs. 619 y ss. Idem, “Fouilles d'Elche», Bulletin Hispanique, n. ${ }^{\circ} 8,1906$, pág. 327; n. ${ }^{\circ}$, 1907, págs. 120-127, propuso que se trataba de una sinagoga. Cuando ya muchos autores habian aceptado esta propuesta, LAFUENTE VIDAL, J., "La supuesta sinagoga d Elche», AEA, n. ${ }^{\circ} 21,1948$, págs. 392-399, valora el edificio como una basílica de los siglos II-II, distorsionando para ello no sólo la datación que proporcionan los mosaicos, sino el no valorar los epígrafes en el contexto en el que se encuentran inmersos.

En el pavimento de la nave central, en una cartela ansata, se lee: pr os euche lao... El término proseuche se utiliza como uno de los vocablos empleados para designar la sinagoga. Es probable que el nombre que debía seguir en la secuencia epigráfica, correspondiese al nombre de la sinagoga, si nos atenemos a los ejemplos romanos, ver en RicciotTi, G., Historia de Israel, vers. castellana. Barcelona 1947, págs.201-204. Para la inscripción, ver FREY, J. B., «Corpus inscriptionum ludaicarum...", op. cit., $n .^{\circ} 662$. Se recogen también las otras dos inscripciones ... icheochonton ke pre(s)biteron, que ya $\mathrm{E}$. Albertini al tratarse de una lectura dudosa, proponia la corrección siguiente: . .. archónton ke pre(s)biteron. La otra inscripción, más defectuosa todavia, se acostumbra a completarse de la forma siguiente: eúploia(n) sy sygch oreson eme euche. Aceptan estas lecturas, FREY, J. B., "Corpus inscriptionum...", op. cit., n. 665 ; A. Ferrua en VIVES, J., "Inscripciones cristianas...», op. cit., n. ${ }^{\circ} 332-333$; CANTERA, F., Sinagogas españolas. Madrid 1954, págs. 212-217; CANTERA, F. y MiLlás, J. M., “Las inscripciones...", op. cit., n. ${ }^{o s}$ 284-286; Garcia IGlesias, L., "Los judios...", op. cit., doc. VIII.

${ }_{67}$ Como sinagoga lo considera inicialmente SCHLUNK, H., "El arte de la época paleocristiana en el Sudeste español. La sinagoga de Elche y el martyrium de la Alberca", en III Congreso arqueológico del Sudeste español. Cartagena 1948, págs. 335 y ss.; Goodenough, E. R., Jewish Symbols in the Greco-Roman Period, VII. Toronto 1958, pág. 177 considera el edificio como una sinagoga, situándolo cronológicamente en la segunda mitad del siglo $\mathrm{V}$. $Y$ como sinagoga lo tiene Applebaum, S., “The Organization...", op. cit., I, págs. 490 y 494; Ramos Feqnández, A., La ciudad romana de llici. Alicante 1975, págs. 241 y Ss.; García IGLesias, L., “Los judios...», op. cit., págs. 16-18 de la separata; BLÁzQUEZ, J. M., "Relaciones entre España y los semitas...", op. cit., pág. 643 . 
Schlunk. Este investigador propuso inicialmente la hipótesis que la sinagoga se hubiera transformado en basílica, en un momento que P. de Palol considera verosímilmente relacionado con la conversión de los judíos de Menorca ${ }^{68}$. Hay que decir que las objeciones de Schlunk no son, en absoluto, nimias. Proseuché también es un término cristiano, utilizado a veces para designar un lugar de oración ${ }^{69}$. Si consideramos que el edificio era inicialmente, o era ya en ese momento una basílica, dicha acepción cristiana no desentonaría con el lugar como tampoco el término presbiteron. Por el contrario, archonton es una propuesta de E. Albertini, no justificada por los signos iniciales del epígrafe.

No son muchas, por tanto, las referencias literarias, ni los testimonios arqueológicos y epigráficos a través de los cuales sepamos inequívocamente de la existencia de comunidades judías en Hispania romana. Además de los datos hasta ahora proporcionados, hay algunos otros como los tres plomos encontrados en Santa María del Camí (Mallorca), ornados con idéntico texto hebreo ${ }^{70}$; datos procedentes de algunos lugares referentes al culto de Sabazios ${ }^{71}$, y hallazgos de monedas acuñadas en tierras

68 Con posterioridad a sus opiniones iniciales SCHLUNK, H., "La sinagoga de Elche e il "martyrium" di La Alberca", Rivista di Archeologia Cristiana, n. ${ }^{28}$, 1952, págs. 182 y ss., piensa que se trataba del aula de una basílica. Esta transformación en basilica, posiblemente en el siglo $v$, de lo que anteriormente era para $P$. de Palol una sinagoga, la pone en relación este autor con la conversión de los judíos de Menorca. Ver al respecto, PALOL, P. de, Arqueología Cristiana en la España Romana. Madrid-Valladolid 1967, págs. 64-67, con bibliografía.

69 Schlunk, H., Hispania Antiqua. Die Denkmäler der frühchristlichen und westgotischeen Zeit. Mainz am Rhein 1978, pág. 145 recuerda que, cual se percibe en inscripciones y textos cristianos (Reallexikon für Antike und Christentum, 8, 1169-1170 Gebet), el término proseuché se utiliza también entre los cristianos, entre otros usos para señalar lugar de oración. Insiste también en el hecho de que la corrección en archonton es arbitraria, ya que ni las letras ni los trazos persistentes, permitían dicha reconstrucción. Y concluye: Bei den Presbyteroi kann es sich ebensowohl um die Altesten einer jüdiscchen Gemeinde wie die Geistlichen einer christlichen Kirche handeln. Gegen eine Deutung als Synagoge sprechen jedoch die gestelzte, halbrunde Apsis und das Fehlen von Darstellungen jüdischer Kulgeräte.

70 Millás, J., “Los plomos con inscripción hebraica de Ses Fontanelles", Sefarad, n. ${ }^{\circ} 18$, 1958, págs. 3 y ss., sitúa cronológicamente estos tres plomos, que ofrecen idéntica inscripción hebrea, bien en el siglo iv o en el $v$. Sobre estos plomos ver también VENY, C., Corpus de inscripciones baleáricas hasta la invasión árabe. Roma-Madrid 1965, págs. 23-24.

${ }^{11}$ Se ha pensado que las presiones sufridas en varias ocasiones por los judíos en Roma pudieron originar su salida hacia otros lugares, entre otros, Hispania. Una de esas ocasiones tuvo lugar en año 139 a.C. Recuerda Valerio Máximo (1, 3,4) que el pretexto utilizado para expuisar a los judios de Roma era que socavaban la moral de los romanos con la contaminación, que producian con el culto de luppiter Sabazius: Cn. Cornelius Hispalus praetor peregrinus ludaeos qui Sabazi lovis cultu Romanos inticere conati erant repetere domos suas coegit. Por esta razón se piensa, y a ello contribuye la semejanza nominal entre Sabazios y Sabaoth, que, quizá, se hubiera podido producir una especie de sincretismo religioso entre Yahvé Sabaot y luppiter Sabazius. Pero no todos los historiadores aceptan esta suposición. Ver estas variadas opiniones en SIMON, M., Le Christianisme antique et son conteste religieux. Scripta Varia. Tübingen 1982, págs. 622-648, que considera que Yahwe Sabaoth y luppiter Sabazius eran equiva- 
hebreas ${ }^{72}$. Aunque ese bagage de evidencia no prueba de un modo fehaciente la existencia de comunidades judias, si que contribuye a reforzar los indicios de mayor entidad. De hecho, tales objetos podrían indicar o bien la presencia de judíos en los lugares en los que se han encontrado, - bien la estancia en Palestina de personas, judías o no, que los hubiesen traído, 0 , en todo caso, una actividad comercial, directa o indirecta, con las tierras de Palestina y aquellas otras del Levante peninsular.

No es muy abundante, como hemos podido constatar, la información disponible sobre judíos de Hispania durante la época romana, ni tampoco menudean los datos relacionados con los mismos. Por eso se consideró oportuno filtrar del caudal de inscripciones romanas de España, aquellas que contenían antropónimos con características semíticas y que, con mayor o menor frecuencia, eran portados usualmente por algunos miembros de las comunidades judías de la diáspora occidental ${ }^{73}$. Para una mejor

lentes. Sobre esta cuestión en relación con la noticia proporcionada por Valerio Máximo, ver LANE, E. n., "Sabazius and the Jews in Valerius Maximus: a Re-examination", $J R S, n .{ }^{\circ} 69,1979$, págs. 35-38, que le otorga poca validez. Parece que el culto a Sabazios se propagó entre los judíos de la diáspora. Ello no supone que los judios fuesen los únicos portadores, o los más numerosos. No hay razones sólidas que permitan sacar una conclusión de este tipo. Los testimonios relacionados con Sabazio en Hispania - dos placas de bronce plateado y la cabeza de Elche--, proceden de lugares como Ampurias - puerto importante y de donde proceden un lote de monedas acuñadas en tierras hebreas - y Elche, ya mencionada con relación a la posible existencia de una sinagoga. Sobre estos testimonios, ver GarCiay BeLLIDO, A., "Una deidad oriental en la España romana. El culto a Sabazios", Revista de la Universidad de Madrid, I, 1953 , págs. 345 y ss.; ldem, Les religions orientales dans l'Espagne romaine. Leiden 1967, págs. 73 81.

72 El hallazgo de monedas en diversos lugares de la Península se ha tomado como exponente de la existencia de comunidades judías en algunos lugares. Quizá resulte excesiva una conclusión de este tipo. El hallazgo de esas monedas en determinados lugares peninsulares, pudiera tomarse como indicativo, bien de que personas, judias o no, las habian traído de tierras hebreas, bien como exponente de una actividad comercial, directa o indirecta, con tierras hebreas. En lo que se refiere a la existencia de esas monedas MATEU LLOPIS, F., uHallazgos monetarios VII", Numerario Hispánico, I, 1952, pág. 239, informa sobre una moneda hebrea, que se halló en Elche. Fuera de contexto arqueológico, una moneda de Herácles Agripa fue hallada en Lluvia, ver Marti Sanjaume, J., Dietari de Puigcerdá l. Ripoll 1926, pág. 78. Por otra parte, del casco urbano de la ciudad de Mataró, antigua liuro, proceden dos monedas de dos procuradores de Judea, ver Gusı, F., challazgo de dos monedas de los procuradores de Judea en lluro (Mataró, Barcelona)", Numisma 1976, págs. 67 y ss. De las excavaciones de Ampurias, procedentes de diversos lugares de las mismas, se obtuvieron once monedas: una de Herodes el Grande, otra de Arquelao y las otras correspondientes a un procurador de Augusto y a otros de Tiberio, ver RIPOLL, E., NUIX, J. M. y VILLARONGA, L., “Monedas de los judíos halladas en las excavaciones de Emporiae", Numisma, n. ${ }^{\circ} 26,1976$, págs. 59 y ss. Sobre ellas, ver GaRCía IGLESIAS, L., "Los judíos en la España antigua...", op. cit., pág. 58.

${ }^{73}$ Con relación a los antropónimos de personas judias, ver el antiguo trabajo, válido todavía en algunos aspectos, de ZUNZ, L., Namen der Juden. Leipzig 1837. El trabajo de LEON, H. J., The Jews of Ancient Rome. Filadelfia 1960 resulta esencial para el estudio onomástico de los judios de Roma, lo mismo que el trabajo de CASsuto, M., "La corrispondenza tra nomi ebraici e greci nell'onomastica judaica", Giornale della società asiatica italiana, n. ${ }^{\circ} 2,1933$, págs. 209- 
consecución de este cometido se tenía a disposición, procedente de otras comunidades extrapeninsulares mejor conocidas, un abundante material onomástico ya estudiado y analizado, que podían servir de pauta y de punto de partida para el estudio y análisis de nombres semejantes expurgados de las inscripciones hispanas ${ }^{74}$. Los procedimientos seguidos por algunos judíos para conservar sus nombres hebreos, bíblicos o no bíblicos ${ }^{75}$, a través de una transcripción o traducción al griego o al latín, así como la alteración, el mantenimiento y la adopción de nuevos nombres de caracteristicas semitas y orientales, tienen, por lo general, rasgos y pautas comunes, que se extienden en un amplio marco geográfico y que los distintos testimonios epigráficos ponen en evidencia; pero cada provincia - y las comunidades urbanas de dichas provincias en las que se asentaron judíos- tuvo su desarrollo peculiar $^{76}$. En el caso de las co-

230. Ver también Milano, A., Storia degli Ebrei in Italia. Turín 1963, págs. 5-45 y 423-436. Una visión matizada y racionablemente rigurosa sobre los judíos y los sirios en la parte occidental del imperio romano, es la que ofrece SoliN, H., "Juden und Syrer in der römischen Welt", op. cit., págs. 633 y ss., con la pertinente bibliografía.

Para las catacumbas judías en Roma e Italia, ver Müllen, N. y BeEs, N. A., Die inschriften der jüdische Katakombe am Monteverde zu Rom. Leipzig 1919; BEYER, H. W. y LIETZMANN, H., Die jüdische Katakombe der villa Torlonia in Rom. Berlín 1930. Como trabajos recientes MAZ. ZOLENI, D., "Le catacombe ebraiche di Roma", Studi Romani, n. ${ }^{\circ} 23,1975$, págs. 289-302; idem, "Les sépultures souterraines des Juifs d'Italie", Les dossiers d'archéologie, n. ${ }^{\circ} 19,1976$, págs. 82-98.

74 Han valorado esos nombres semitas, considerando algunos de ellos como posibles nombres portados por judíos GARCiA Y BELLIDO, A., "El elemento forastero en Hispania Romana", BRAH, $n .{ }^{\circ} 144,1959$, págs. 119-154; BLAZZUEZ, J. M., "Relaciones entre hispania y los semitas...", op. cit., págs. 641-643; Garcia lglesias, L., “Los judíos...», op. cit., pág. 12 de la separata; idem, "Los judios en la España antigua...", op. cit., pág. 54 ; KoCH, M., “Zur frühen jüdischen Diaspora...", op. cit., pág. 249, nota 59 y pág. 254.

75 Ver al respecto COHEN, N. G., "Jewish names as cultural indicators in Antiquity", Journal for the Study of Judaism, $n .{ }^{\circ} 7,1977$, págs. 97-128; referencias bibliográficas al respecto se encuentran recogidas en Singerman, R., Jewish and Hebrew Onomastics. A Bibliography. Nueva York-Londres 1977.

76 Procedente de todo el Imperio se dispone de un rico y amplio material, que permite establecer diversas categorías, que su misma frecuencia dentro de un contexto judío contribuye a reforzar. En este sentido no hay que perder de vista que los cognomina griegos muy populares y respetados. Ver al respecto CALDERINI, A., Aquileia romana. Milán 1930, pág. 417, quien afirma que también los Romanos ponían cognomina griegos a sus hijos. Por su parte, Gordon, M. L., "The Nacionality of Slaves under the Early Roman Empire", JRS, n. ${ }^{\circ} 14,1924$, págs. 93-111 aprecia que los cognomina griegos se dan entre esclavos orientales y occidentales. También THYLANDER, H., Étude sur l'épigraphie latine. Lund 1952, págs. 167-169, basándose en los trabajos de LEON, J. H., TAPA, n. ${ }^{\circ} 58,1927$, págs. 210-333; n. ${ }^{\circ} 59,1928$, págs. 205-224, frente a aquellos que minimizan la tendencia "orientalizadora", señala que muchos cognomina griegos y latinos se dieron a libertos e hijos de libertos de procedencia oriental. Teniendo en cuenta los diversos estudios sobre estos nombres, se ha podido constatar que muchos cognomina griegos y latinos, que se han recogido en los contextos judios anteriormente indicados, parecen responder algunos de ellos a traducciones al griego o al latín de nombres hebreos. Otros nombres, sin embargo, parecen haber adoptado formas muy semejantes a aquellas hebreas. 
munidades hispanas con población judía, hay que tener presente que se trata de comunidades que no ofrecen abundancia de inscripciones pertenecientes a judíos, ni procedentes de necrópolis judías, ni de un lugar concreto que pueda considerarse como un contexto judío y que haya podido aportar, por ende, más inscripciones y nombres de tales características. Eso hace que - a diferencia de lo que puede ocurrir en comunidades judías como la de Roma y sus necrópolis judías, que permiten establecer esos paralelos--, se corran grandes riesgos a la hora de valorar en una inscripción hispana como judío un nombre semita oriental, por el hecho de que ese nombre en otro lugar con fuerte comunidad judía fuera llevado por una persona judía.

En función de esos paralelos onomásticos son varios los antropónimos de personas, para los que se postula hipotéticamente una procedencia judía. Entre éstos se encuentran nombres de mujeres como Chaldaea, procedente de una inscripción de Saetabis, Játiva, y Rubena, de Tarragona ${ }^{77}$; Sulpicia Su(ccess)a de una inscripción de Tarragona y Aemilia Meliusa de una de Cartagena, que llevan congnomina considerados en otros lugares como correspondientes a personas de clara procedencia judía ${ }^{78}$. Esta coincidencia y el hecho de que las inscripciones en cuestión procedan de lugares del litoral de gran importancia comercial y dotados de fuertes colonias orientales - que en el caso de Tarragona estaria, además, avalado con posteriores testimonios judíos- ha hecho suponer que pudiera tratarse de nombres llevados por mujeres judías. De hecho, el nombre Meliusa, al igual que el de Mares/Maries, se encuentran testimoniados en la zona en la inscripción trilingüe - hebreo, latín y griego-

${ }^{77}$ CIL II, 3635 procedente de Játiva: Corneliae/ P. F./ Propinquae/ Chaldaea. Q. F./ Verecunda. Mater. La CIL II, 4402 procede de Tarragona. Rubena...A/ Sura. Carter/ Hinc sitast. GaRcía IGLESIAS, L., “Los judíos...", op. cit., pág. 12 y “Los judíos...”, op. cit., pág. 54, considera que pudiera tratarse de nombres llevados por personas hebreas. Con relación a la explicación de ALFOLDI, G., “Die römischen Inschriften...», op. cit., n. 15, de la inscripción de Tarragona, recuerda el primer autor que se trata del nombre de mujer. Pero respecto a estos nombres, hay que tener presente que se trata de gentilicios. Por esta razón SoLIN, H., "Juden und Syrer...", op. cit., pág. 751 , les concede pocas garantías de que sean judios y por eso los incluye en el apartado de nombres semitas.

${ }_{78}$ La inscripción de Tarragona en CIL II, 4298: L. Fluvio/Musaeo/ seviro Aug./ Su(lpic)ia / Su(ccess)a/ ma(rit)o/ optimo. Este cognomen se encuentra testimoniado, como puede observarse en LEON, J. H., "The Jews...", op . cit., págs. 99 y 107, entre los judios occidentales. KoCH, M., “Zur frühen...», op. cit., pág. 249 , nota 59 y pág. 254, piensa que pudiera tratarse de una judia. Lo mismo piensa este autor con relación a Meliusa registrada en la inscripción de Cartagena, CIL II, 3446: Aemi/lia Mel/iusa/M. L. Saca esa deducción, utilizando paralelos onomásticos observados por LEON, J. H., “The Jews...», op. cit., págs. 103 y por CASsuto, M., op. cit., págs. 222 y s. Ciertamente el nombre se encontrará luego registrado en la zona para denominar a una persona judia, ver VIVES, J., «Inscripciones cristianas...", op. cit., n. ${ }^{\circ} 428$, correspondiente a la inscripción de Tortosa. 
de Tortosa, de inequívoco carácter judaico. En lo que hace a Bassamia/ Bassania de una inscripción de Córdoba -en la que también se menciona al sacerdote Aurelius Stephanus, cuyo cognomen es llevado en otros lugares por judíos-, no parece que debamos considerarlo como llevado por una mujer judía ${ }^{79}$. El contenido de la inscripción nos remite a un taurobolium y a un criobolium, que se explican muy bien en ambientes semitas. En Cádiz, de donde procede una inscripción que menciona a una esclava denominada Maria, se constata también un antropónimo lunia Simmodin, en la que el último término es un cognonen, sobre el que se han hecho algunas consideraciones para valorarlo como relacionado con un nombre ibérico, $o$, lo que parece más probable como nombre semita, que en opinión discutible de algunos autores, estaría designando a una judía. La profunda tradición oriental de la ciudad, patente por datos significativos, refuerzan el posible carácter semítico de $\operatorname{Simmodin}^{80}$ :

Anna, Maria y Marta, contenidos en inscripciones procedentes de varios lugares peninsulares, dan pie a diversas consideraciones. Anna es un nombre que se encuentra relativamente bien difundido por todo el territorio peninsular, tanto en el área no indoeuropea ${ }^{81}$, como en la indoeuropea, en donde la difusión del nombre no obedece a influencia oriental y mucho menos a influencia judía. En este sentido, sólo parece que debieran ser objeto de adecuada consideración aquellas inscripciones que proceden de lugares situados en zonas alejados del área indoeuropea, que por otra

79 C/L II, 5521: Ex iussu matris deum/ pro salute imperii/ tauribolium fecit Publicius/ Valerius Fortunatus Thalamus/ suscepit crionis Porcia Bassenia/ sacerdote Aurelio Stephano/ dedicata VIII Kal(endas) April(es) Pio et Proculo co(n)s(ulibus), en la que Porcia Bassemia figura en un taurobolium y en un criobolium, ver BLÁzQUEZ, J. M., "Relaciones entre Hispania y los semitas...", op. cit., pág. 641. En esta inscripción se menciona también un sacerdote, que lleva Stephanus en su denominación, nombre que no es infrecuente entre los judios de la parte occidental del Imperio, como manifiestan LEON, H. J., op. cit. y KoCH, M., op. cit., pág. 249, nota 59. Parece que la ciudad de Córdoba contó con una comunidad siria importante. Se constata no sólo por el nombre semita de esta inscripción, sino por alguno más procedente de esa ciudad. Así, Thaddai egistrado en la inscripción CIL II, 2232 de un puteal; el cognomen Surillo, relacionado con Syrus, Surus, Syriacus, de gran difusión en Hispania - ver mapa en el trabajo señalado de Koch - y que se encuentra registrado en la inscripción cordobesa $C I L ~ I I, 5526$, aludiendo a $Q$. Annedius Q.1. Surillo.

${ }_{80}$ CIL II, 1837: Iunia. M. F./Simmodim/H.S.E. t. R./P.D.S.T.T.L. ALbertos, M. L., La onomástica personal primitiva de Hispania Tarraconense y Bética. Salamanca 1966, pág. 208, no se plantea la cuestión de un posible origen semita de este cognomen y lo considera como de procedencia ibérica. El fenómeno - $\mathrm{mm}-$, por frecuente en ibérico, lo considera (ALBERTOS, $M$. L., op. cit., pág. 63) como asimilación de -nb-- en -mm-- GaRCiA IGLESIAS, L., "Los judíos...", op. cit., pág. 12 de la separata; "Los judíos...", op. cit., pág. 63, la considera como judía, al igual que KoCH, M., "Zur frühen...", op. cit., pág. 250.

81 Albertos, M. L., "La onomástica personal...", op.c it., págs. 26-27 y «Nuevos antropónimos hispanos (2." serie)", Emerita, n. ${ }^{\circ} \mathrm{XL}, 1972$, pág. 11, en donde recoge la lista de estos antropónimos de origen infantil. 
parte disponen de otros testimonios de carácter oriental. Así, Anna, nombre de una liberta, está recogida en una inscripción de Alcalá del Río y en una inscripción incompleta de Castellón de Ampurias, Gerona ${ }^{82}$, y ya sabemos que en Ampurias se obtuvieron monedas acuñadas en tierras hebraicas y dos placas relacionados con Sabazios. Ya en época helenística, lo mismo que en época romana, se hacían traducciones al griego y al latín de nombres semitas y judíos o se acomodaban de un modo elemental las secuencias fonéticas semíticas a la fonética griega o latina. No hay que cerrar, por tanto, la puerta a la posibilidad de que en algunos casos Annia sea una acomodación y derivación del nombre bíblico Anna. Tal ha podido ocurrir con (An) nia Sabo (mo )nula de la inscripción de Adra, pero, en el caso de las inscripciones que estamos contemplando, ya de suyo breves e incompletas, no parece que el nombre de Anna, haya que asumirlo en una dimensión étnica; ni siquiera, quizá, aunque esto ya no sería tan improbable, como indicativo de una procedencia oriental de los personajes en cuestión, si bien el nombre es semita. Los nombres de Maria y Marta no son nombres del Antiguo Testamento; pero aparecen frecuentemente utilizados en las inscripciones hebraicas y cristianas. En esos casos, los contextos en los que están inmersos, cristianos o judaicos, aportan las connotaciones propias a partir de las cuales se puede determinar el carácter cristiano o judio de la persona que lleve el nombre o el cognomen Maria. Las inscripciones que lo testimonian como cognomen de una liberta de Mérida, de Cartagena, de Tarragona, y de una persona de condición servil de Cádiz ${ }^{83}$, no presentan contexto judío; antes al contrario, alguna de ellas ofrece rasgos en sentido contrario. Por ello, la atribución de un origen judio a sus portadores resulta altamente problemático. De los denominados con estos nombres y con otros semejantes sólo puede concluirse - si se dispone de otros indicios, y no en todos

82 Para la inscripción de Alcalá del Río, CIL, n. Il, 1092: Attenia/ L.L. Anna/ Have; MANGAS, J., Esclavos y libertos en la España romana. Salamanca 1971, pág. 484, la considera como liberta. Para la inscripción de Castellón de Ampurias, Gerona, HAE, n. ${ }^{\text {os }} 6-7,1955-1956, n{ }^{\circ} 801$ : lus...Hero.../ et. Annae/Q. sibi. et.../...i.../.

83 Para la inscripción de Mérida, C/L II, 517: Claudiae. Mariae. Pac(e)n(ti)/ Ti. Claud. Artemidorus; GaAcia lgLesias, L., "Los judíos...", op. cit., pág. 65, nota 142. La de Cartagena CIL II, 5935: Vergiliae/Caesiae/ Maria. I. de suo/ (fa)ciundum. curavit. La de Cádiz, HAE, n. ${ }^{\circ} 12-16$, 1961-1965, n. ${ }^{\circ}$ 2012: Maria/ Veneris cara/ suis ann(orum) XXXV/H.S.E.S.T.T.L. MANGAS, J., “Esclavos y libertos...", op. cit., pág. 394. Para la inscripción de Tarragona, referente a una liberta acogida a la fórmula pagana de D.M., ver CIL II, 4362: D. M./Fabiae Mariae Quae Vixit/Ann(orum) XXXIIII. M. VIII. Fab. Mau/rula. Mater. Fab. Parilis. Fra/ter. Et. Lupus. Maritus/ Coniugi Pientis$\operatorname{sim}(0) /$ B.M.F. ALFÖLDI, G., "Die römischen Inschriften...", op. cit., n. 567 . Para la opinión de que, fuera de contexto judío, el nombre Maria, quizá no pueda tomarse como inapelable indicativo de un origen hebreo, o incluso oriental, de la persona en cuestión ver SoLIN, H., "Juden und Syrer...”, op. cit., págs. 641-647. 
los casos-, que se trata de orientales. Y, en este sentido, lo que sí queda claro es que las inscripciones que contienen el término Maria provienen de lugares que resultan ser importantes centros comerciales, provistos, además, de sólidas colonias orientales. $Y$ consideraciones y valoraciones del mismo tenor pueden hacerse respecto de aquellas inscripciones que contienen Marta en la denominación de una liberta de Córdoba, de otra de Mérida y de dos de Cartagena ${ }^{84}$.

Es evidente que los romanos no se mostraron reacios a recibir en su ámbito de dominio lingüístico nombres foráneos, porque dichos nombres alcanzaron una gran difusión. En la imposición a los esclavos de esos nombres orientales, los comerciantes, los intermediarios y dueños de esclavos han desempeñado un papel importante. En la amplia difusión alcanzada por los nombres semitas, Malchio -acomodo de Malchus, casi exclusivo entre libres en la parte occidental del Imperio- y el femenino Malchis, Malche, llevado predominantemente por los esclavos, constituye un hito y un punto de referencia. No todos los esclavos que llevaban tal nombre pueden ser considerados como de procedencia oriental: no fueron pocos los que, nacidos en la parte occidental del Imperio, lo recibieron. En Hispania, curiosamente, se encuentra muy representado. El nombre, como denominación de un liberto se encuentra contenido en una inscripción de Cartagena ${ }^{85}$, en donde se cuenta con otros datos, mediante los cuales se constata la existencia en esa ciudad de una comunidad oriental. De Córdoba procede un puteal dedicado por un personaje denominado Thaddaus. Este nombre, que, como una posibilidad más, está considerado como indígena, es, por el contrario, considerado por otros autores como un nombre de procedencia oriental; lo cual no supone, como se ha propuesto, que correspondiera a un judío ${ }^{86}$. De la misma ciudad procede

B4 Tomando de estas inscripciones sólo la parte del texto que contiene el término Marta, ver de la inscripción de Córdoba CIL II, 2282: Petilia T. L. Marta...H. S. Est. T. T. L. S. Para las de Cartagena, CIL II, 3483: ...t. I./ ...Marta/ ...hic. sit; CIL II, 3507: Titinia. ). I./ Marta/ hic. sita est/ Ave. Vale. Para la de Mérida, E.E., VIII, Hisp. 271: D.M.S./ Sempronie Marte Semp. Firmus uxo(ri). Indudablemente Maria y Marta son nombres que acostumbran a llevar mujeres judias en otros lugares que cuentan con comunidades judías, p. ej. en Roma. Ver el respecto LEON, H. J., "Jews...", op. cit., pág. 105. Pero esto no supone, como si se tratara de una derivación mecánica, que en aquellos lugares en los que se registran esos nombres se dan consecuentemente comunidades judías. $Y$, en este sentido, los casos hispanos no son lo suficientemente explícitos como para poder concluir que se trata de personas judías.

85 E.E., 9,339: M. Labicius /) L./ Malcio. Así lo registra MANGAS, J., "Esclavos y libertos...", op. cit., pág. 413. Se trata, con muchas probabilidad, del usual nombre de Malchius. Sobre la "helenización" inicial de este nombre, ver MAsso, O., "Quelques noms sémitiques en transcription grecque à Délos et à Rhénée”, en Hommages à A. Dupont-Sommer. París 1972, págs. 6173.

86 CIL II, 2232: Puteal/Thaddai. García y Bellido, A., El distylo sepulcral romano de lulipa (Zalamea). Madrid 1963, pág. 73 piensa que se trata de un sitio que dedica ese puteal a una 
una inscripción que recoge el nombre de Barnaetus, correspondiente a un liberto ${ }^{87}$. De Santaella, cercana a Écija, proviene una inscripción alusiva a un esclavo, vilicus de un latifundio, de nombre Sabdaeus, sobre el que se apunta la posibilidad de que sea un esclavo judío. En otros lugares extrapeninsulares, y fuera de contextos judaicos, el nombre, de clara procedencia semítica, es portado también tanto por personas esclavas y libertas como por libres ${ }^{88}$.

En Peñaflor se ha hallado una inscripción que recoge el cognomen Barathes ${ }^{89}$, del que se considera poco probable que corresponda a un judío, por el hecho de que la inscripción está acogida a la fórmula pagana D. M. S. Barathes, al igual que su otra forma Barcates ${ }^{90}$, testimoniada en una inscripción del territorio de Begis del Castillo, tiene una clara ascendencia semita. También en este caso se trata una vez más de uno de

divinidad, que no está mencionada. BLÁZQUEZ, J.M., "Relaciones entre Hispania y los semitas...", op. cit., pág. 641 , cree que el nombre es "puramente siríaco" y que se trata de un puteal dedicado a una ciudad (?), cuyo nombre no se señala. SoLIN, H., "Juden und Syrer...", op. cit., 751, piensa que el nombre no pertenece a un judio, tal y como quiere $R$. Thouvenot. Pudiera tratarse de indígena. Para la consideración del nombre como judío, ver THOUVEnOt, R., Essai sur la province de Bétique. París 1940, pág. 186; García IGLESIAS, L., “Los judíos...”, op. cit., pág. 51, afirma que el nombre es sitio, aunque también lo llevan los judíos. El hecho de que se trate de un puteal hace difícil que pueda referirse a un judío. Косн, M., "Zur frühen...», op. cit., pág. 249, nota 59 dice que A. García y Bellido y J. M. Blázquez lo consideran como judío.

${ }^{87}$ H.A.E., n. ${ }^{\circ 5}$ 1-3, 1950-1952: L. Postumus. Barnaetus/ hic. s. t. $t .1 . /$ ). l.; Mangas, J., "Esclavos y libertos...", op. cit., pág. 436. García IGLESIAS, L., "Los judíos...", op. cit., 64, lo considera como nombre que designa a un posible judío. El nombre se toma como de procedencia semita en cuanto que pertenecería a ese grupo de nombres formados sobre Bar- "hijo", que se encuentran ampliamente difundidos entre esclavos, libertos, pero también libres, en la parte occidental del Imperio.

${ }^{88}$ CIL II, 1552: Sabdaeus/vilicus/ annor(um) LIII/ h. s. est. s. t. t. I. КоСH, M., "Zur frühen...", op. cit., pág. 249, nota 59, recogiendo la información de LEón, H. J., “Jews...", op. cit., pág. 105 , nota 6 , piensa que este nombre utilizado por los judíos guarda relación con la raiz hebrea H'TLT. Considera también que, probablemente, el nombre denomina a un esclavo judío. Garcia IGLESIAS, L., "Los judíos...», op. cit., pág. 64, lo toma también como judío. Este nombre se encuentra ampliamente difundido en su forma Zabda entre los esclavos, libertos y libres. Por los datos de que se dispone, no todos los casos pertenecen necesariamente a judíos. Para la difusión de Zabda, ver SoLIN, H., "Juden und Syrer...", op. cit., pág. 677, para esclavos y libertos, y pág. 682 para las personas libres.

${ }_{89}$ Para esta inscripción, ver CHIC, G., “Inscripciones de Peñaflor», Habis, n. ${ }^{\circ} 6,1975$, págs. 362-363; $A E, 1975$, pág. 504. Tomamos del texto de la inscripción la parte que contiene el nombre en cuestión: D.M.S...Pietati Baeticae annorum XXI...Barathes coniugi. GARCiA IGLESIAS, L., "Los judíos...", op. cit., pág. 64, aunque admite que pudiera tratarse de un nombre semita, no lo considera que pertenece a un judío en razón al D.M.S., que mantiene la inscripción. Sobre este nombre, ver ZUCKER, F., "Semitische Namen auf den neu gefundenen Inschriftenstelen von Minturnae", Hermes, n. ${ }^{\circ} 78,1943$, pág. 201. Para su difusión entre esclavos, libertos y entre personas libres, ver SoLIN, H., "Juden und Syrer...", op. cit., págs. 677 y 680 .

${ }^{90} H A E, n{ }^{\circ 5} 6-7,1955,1956, n .{ }^{\circ} 950:$.../C. Viccus B/arcates an (norum) LXX/H.S.S. ALFÖLDI, G., op. cit., lee: .../Cuiccius B/arcates an. $L X X / H . S . S$. Para la difusión de este nombre entre esclavos, libertos y libres, ver SoLIN, H., "Juden und Syrer...", op. cit., págs. 677 y 680 . 
esos nombres que se han formado con Bar- «hijo»: Barathes/Bargathes "hijo de Ate". Otros tres nombres recogidos en inscripciones hispanas parecen formados a partir de Bar-, por lo que, de ser correcta esta configuración del nombre, habría que considerarlos, en principio, como nombres semitas. Uno de ellos es Baritto, con el que se firma uno de los mosaicos de Mérida y que para denominar a un esclavo se encuentra también registrado en una inscripción de La Toscana, cerca de Bailén. Para el caso registrado en Mérida, no disponemos de datos significativos que hagan suponer que se trata de un hebreo. Sin duda que este nombre -que parece semita, pero para el que se ha propuesto otra explicación etimológica-, no es el único testimonio registrado en esta ciudad de los que hacen patente la existencia de la comunidad oriental. Respecto al esclavo de la inscripción de La Toscana, que en buena lógica hay que asumirlo también como semita, no se consideraría, en opinión de algún autor, como judio, en razón de que la inscripción recoge la fórmula D.M.S. ${ }^{91}$. Caecilius Barsamis está recogido en una inscripción procedente de Segobriga (Cabeza del Griego, Saelices, Cuenca) para designar a un liberto, que portaba un cognomen como Barsamis ${ }^{92}$. El nombre de su mujer Caecilia Pamphila nos remite a la tendencia a poner nombres griegos y orientales a los esclavos, que conservan después de la manumisión, tomando, además, el nombre de su antiguo dueño. No resulta, por tanto, improbable que el cognomen tenga ascendencia semita, que es lo que ha servido de punto de apoyo para suponer que se refería a un judío; pero el hecho es que el cognomen admite también una lectura etimológica en clave indoeuropea, en lógica consonancia, por un lado con el área territorial indoeuropea en la que se encuentra ubicada Segobriga $y$, por otro, con el propio topónimo con el que se denomina a la ciudad.

91 FORNI, G., en el diálogo mantenido y recogido en las Actas correspondientes a Augusta Emerita. Actas del Bimilenario de Mérida. Madrid 1976, pág. 73 , al valorar que el nombre se ha formado a partir de Bar-, concluye que el nombre, que aparece en el mosaico corresponde a un hebreo. GARcía IGLESIAS, L., "Los judíos...", op. cit., pág. 66 , lo toma como judío. La inscripción de la La Toscana está en C/L II, 5911: D.M.S./Baritto an(norum)/XXXVII.hic/s. est.s. t./t. I. Albertos, M. L., "La onomástica primitiva...», op. cit., pág. 50, considera posible que Barita sea una variante de este nombre, que lo valora como un antropónimo britano, para lo que se apoya en The Dialects of Ancient Gaul. Ann-Arbor 1959-1950. GarciA IGLESIAS, L., "Los judíos...", op. cit., pág. 66, no lo toma como hebreo porque la inscripción está presidida por la fórmula D.M.S.

92 CIL II, 3130: Caec. Pamphi/le. an. XXXII/ M.X.D. XVI/ Caec Barsa/mis uxori. Ver también Almagro BASCH, M., Segobriga II. Inscripciones ibéricas, latinas paganas y latinas cristianas. Madrid 1985, págs. 222-223, n. ${ }^{\circ} 91$. GARCíA IGLESIAS, “Los judíos...», op . cit., pág. 66, en razón a los nombres y a la ausencia de fórmulas paganas, cree que ambos personajes son posibles judios. Albertos, M. L., "La onomástica primitiva...", op. cit., pág. 50 , piensa que el radical de este nombre está relacionado con la raíz indoeuropea bhars-. Sobre este radical se han formado topónimos como Barsa, Barsanica, situados en el área de dominio lingüístico indoeuropeo. Almagro BASCH, M., "Segobriga II...", op. cit., pág. 223, sigue también esta opinión. 
Otro nombre, posiblemente formado también con Bar-, es aquél de Baravel, contenido en una inscripción procedente de Ávila, nombre semita, que algunos creen corresponder a un judío ${ }^{93}$. Una inscripción de Nabrissa (Lebrija) contiene el cognomen de un liberto bajo la forma Asra o Asrau, que pudiera estar encubriendo, como ocurre en otros muchos casos, un nombre hebreo, en este caso Esdras ${ }^{94}$.

Es harto difícil esbozar ni siquiera en sus líneas generales una historia de los judíos en la Historia Antigua. Las fuentes antiguas son escasas, están orientadas en una dirección ético-religiosa específica y dejan por esta razón importantes lagunas sin cubrir. No falta, ciertamente, material epigráfico, aunque la información que proporciona es parca y escasa, a lo que en cierta manera no son ajenas las limitaciones que el usual esquema seguido en la redacción del texto epigráfico acostumbra a imponer. Son pocas, ciertamente, las inscripciones encontradas en Hispania que puedan atribuirse, indiscutiblemente, a personas judías. Son, por el contrario, más abundantes aquellas inscripciones que en su texto contienen nombres semitas y orientales idénticos a aquellos otros que en otras tierras occidentales del Imperio romano llevaban personas que eran en verdad judías. Esta constatación permitía establecer comparaciones y realizar estudios onomásticos. De esta forma se ampliaba el número de epígrafes sometidos a consideración. El material epigráfico, por tanto, no es uniforme ni todos los epígrafes tienen las mismas garantías de paternidad judia. Todos ellos, no obstante, tienen algunos puntos en común. A este respecto, de la plasmación cartográfica de los lugares de los que proceden las inscripciones indiscutiblemente pertenecientes a judíos y de aquellas otras que llevan nombre semitas y orientales, que en otras partes del Imperio corresponden a judíos, se constata que la mayoría de ellas proceden de ciudades importantes y prósperas de la costa y de vías fluviales en donde no es infrecuente que se registren comunidades de comerciantes orientales y se tengan testimoniados cultos orientales.

Las inscripciones consideradas se concentran, como hemos dicho, en ciudades portuarias - Tarragona, Cartagena, Cádiz, etc.-, ciudades situadas en el litoral - Elche, Játiva, etc.-, y ciudades cercanas a importantes rutas fluviales -Córdoba, Mérida, etc.-, en definitiva, ciudades

93 CIL II, 3050: Q. Coron. Q. Coron. Verni. F. Quir. Ber/avel An. LXX/Veranius. Veranii Verni F. M. H. F./ H.S.E.T.T.L. Lo valora como posible hebreo García IGLESIAS, L., "Los judíos...", op. cit., pág. 12 de la separata; idem, "Los judíos...", op. cit., pág. 66. Pensamos con Solin, H., "Juden und Syrer...", op. cit., 751 que el contexto en el que está inmerso este nombre no es ni judio ni sirio.

94 CIL II,1 300: LID/AsraU/IINVA/ MATER. Lo considera judio Garcia IGLESIAS, L., "Los judíos...", op. cit., pág. 64 . 
que, como sabemos por otros numerosos indicios, se destacan dentro del contexto hispano por sus actividades comerciales. $Y$ esta coincidencia no es casual; lo cual no supone que los judíos de esas zonas, se dedicasen, inevitablemente, a las actividades comerciales y que sean predominantemente ricos comerciantes. Las inscripciones apuntan más bien en sentido contrario. Los aspectos materiales de aquellas inscripciones conservadas responden a la usual y reiterada mediocridad que caracteriza las inscripciones relativas, en general, a los sectores modestos de la sociedad. De forma parecida, el contenido de la inmensa mayoría de las inscripciones consideradas es breve y modesto. Es razonable pensar, por tanto, que, aunque pudiera haber comerciantes e incluso latifundistas, como se constatará literariamente para una época posterior, la mayoría de las personas registradas en esos epígrafes y mencionadas por diversos investigadores como judíos o como posibles judíos fueran pequeños artesanos y operarios utilizados en actividades artesanales y comerciales. No hay que cerrar las puertas a la suposición de que, aprovechando las actividades mercantiles en las que estuvieron inmersas amplias zonas hispanas, en parte debido a las enormes cantidades de suministros que debían proporcionar a Roma, se instalasen en ellas judios portadores de recursos propios, de condición libre, e incluso, posiblemente provistos de la ciudadanía romana. Pero los que nos documentan los testimonios epigráficos - los epígrafes con nombres griegos seguros y los que tienen nombres probables- son gentes de poco recursos, gentes de condición servil que debian instalarse donde radicaban los negocios de sus dueños y personas de condición liberta cuyas posibilidades de abrirse paso se encontraban en aquellos lugares más acordes con el ejercicio de sus actividades anteriores. Así, del estudio de estos epigrafes, se percibe que se trata de personas de condición esclava y liberta. En este sentido, si centramos nuestra consideración en la condición social de los judios hispanos, e, incluso, si la ampliamos a aquellas personas documentadas en las inscripciones con antropónimos semejantes a los que llevan algunos judios en otros lugares, se percibe que se trata, mayoritariamente, de personas de condición social poco elevada, si tomamos como punto de referencia la escasa presencia de tria nomina y de gentilicios.

Es cierto que algunas inscripciones contienen indicaciones esporádicas acerca del lugar de procedencia de algunos judíos. Pero eso no es lo habitual. $Y$ ello hace que desconozcamos de dónde procedía la mayoría de los judíos asentados en Hispania. Consecuentemente, resulta imposible constatar la instalación en la Península de comunidades provenientes directamente de tierras hebreas. Aquellas inscripciones, muy pocas, que registran la indicación del lugar de procedencia de los personajes ofrecen un panorama variado, pues, o bien nos remiten a tierras de Samaria, a 
la colonia Flavia Neapolis (Sichen) de donde viene un personaje recogido en una inscripción, quizá del siglo III, encontrada en Mérida, o bien nos llevan a Cícico en la Propóntide, de donde es originario el rabino Latouves (en griego, Lasies en latín) aludido en una inscripción del siglo IV como más temprana, hallada en Tarragona o bien a Pitermon, en Egipto, de donde procede un personaje denominado Nectaris, considerado sin seguridad como judío. Ya hemos plasmado anteriormente las consideraciones respecto a una temprana presencia judía en la Península de la mano de los fenicios y de los púnicos. Pero también hemos señalado que, pese a la posible temprana presencia judía, pese a esos viejos lazos con los fenicios y quizá también púnicos y pese a la constatación, para época posterior de comunidades judías en tierras que fueron libiofenicias, no se cuenta con las pertinentes garantías que aseguren la ininterrumpida continuidad hasta época romana.

Se ha considerado hipotéticamente que en los nuevos aportes poblacionales judios que se instalaron en Hispania, las comunidades judias de la parte oriental del Mediterráneo, especialmente aquella de Alejandría, debiera de jugar una baza no pequeña. Las revueltas judías entre el 115117 en Alejandría, pero también de Cirene, Chipre y otros lugares ${ }^{95}$, no sólo se cobraron muchas vidas, tal y como recuerda Dión Casio (LXVIII, 32 ), sino que también debieron de provocar muchos desplazamientos. A partir de esos acontecimientos, la ascendencia que ejercía la comunidad de Alejandría, penetrada de cultura helenística, sobre los judíos de la diáspora occidental decayó sensiblemente. Y, a este respecto, hay que tener presente que el hallazgo en algunas ciudades de inscripciones trilingües - hebreo, griego y latín-, bilingües -latín y griego- y griegas no es indicativo de una inequívoca procedencia judía de tierras palestinas y orientales. Bien es cierto que la supremacía del latín como lengua de las inscripciones y la abundancia de la onomástica latina en las mismas, no pueden tomarse como exponente cierto contra la propuesta hipotética de la procedencia de los judios hispanos de las tierras orientales en las que se hablaba griego. En este sentido hay que tener presente que la asimilación y la latinización, como pone de manifiesto la abundancia de inscripciones, se impuso rápidamente. De manera semejante, en la asignación del nombre a esclavos y libertos se está expuesto a las modas onomásticas, otorgando, entre otros, nombres griegos y semitas, y a se-

95 Fuks, A., "The Jewish Revolt in Egypt A. D. 115-117 in the Light of the Papyri», Aegyptus, n. ${ }^{\circ} 33,1953$, págs. 131-158; idem, "Aspects of the Jewish Revolt in A.D. 115-117", JRS, 1961, págs. 98-104; SMALLWOOD, E. M., “Palestine C. A.D. 115-118", Historia, 1962, págs. 500-510; GRANt, M., "The Jews in the Roman World...", op. cit., págs, 237 y ss. 
guir la tradición y las influencias de la población circundante. Por otra parte, hay que tener presente que estas inscripciones se remontan en Hispania lo más temprano al siglo Iv, es decir a una época tardía, cuando la hebraización está ya muy avanzada en la parte occidental del Imperio $y$, por otra, la pervivencia en algunas comunidades judias de Hispania de la utilización, además del hebreo, del griego se explica, al margen de posibles relaciones con comunidades judias de la parte oriental del Imperio, por su uso persistente dentro de contextos orientales relativamente cerrados.

Se ha pensado también que muchos de los judíos asentados en Hispania han podido proceder de Roma, de Italia y en menor proporción de África. Se trata de una propuesta hipotética, cuya formulación se apoya en indicios razonables. Se ha insistido en la sólida latinización de los nombres contenidos en aquellas inscripciones que presentan algunos antropónimos judíos o están llevados por judíos; en el predominio, en otras, del nombre latino, mientras que el cognomen es semita, hebreo o griego en las denominaciones de otras personas documentadas en las mismas inscripciones que recogen nombres de judíos o nombres y cognomina que acostumbran a llevarlos los judíos de otras zonas. Pero la latinización no sólo es un fenómeno romano e itálico, sino que alcanza y actúa en todas las partes del Imperio donde el latín domina decisiva y predominantemente. Por otra parte, en la imposición del nombre, griego, latino o semita, a esclavos y libertos $-y$ a estos estratos sociales corresponden la mayoría de las inscripciones recogidas por algunos autores como referidas más o menos hipotéticamente a judíos hispanos - el dueño tiene un papel decisivo. Pero este papel no es exclusivo de Italia y Roma, sino que es generalizable a todo el Imperio. No puede tomarse, por tanto, como indicio indiscutible de una inexcusable procedencia romana de los judios hispanos sólo en razón de la semejanza, numéricamente no escasa, entre nombres de judícs de Roma y de Italia y aquellos que llevan algunas personas en inscripciones procedentes de lugares hispanos que, por otros indicios y datos coetáneos o posteriores, conocemos que han tenido comunidades judías y orientales.

Por diversos criterios, no siempre decisivos y fiables, se supone que algunas de estas inscripciones pueden situarse en el siglo l; pero la mayoria de ellas corresponden a los siglos $\mid$ y III. Son pocas las inscripciones correspondientes a época romana anterior a las invasiones de comienzos del siglo $v$ que contengan indicaciones expresas y connotaciones implícitas que señalen, por un lado, y de las cuales pueda deducirse, por otro, la procedencia de tierras palestinas de la persona aludida o su condición de judio. Ya nos hemos referido a la inscripción de Mérida, posiblemente del siglo II, en la que el término Neapolitanus que porta lustinus Menandri 
(filius) Flavius es un indicativo de la procedencia de este personaje de la colonia Flavia Neapolis en tierras de Samaria, pero no recoge ninguna otra sólida indicación o connotación que aluda a algún elemento de carácter cultural y religioso hebreo. La inscripción contiene tres nombres latinos y dos griegos, pero ninguno semita. No hay datos suficientes que permitan postular que en este caso lustinus sea la traducción latina de un nombre hebreo. Pero, al margen de esta indicación de procedencia geográfica, del contenido epigráfico de esta inscripción no se puede deducir que el personaje en cuestión o sus deudos hayan hecho manifestación de su pertenencia étnico-religiosa al pueblo judío.

Es preciso preguntarse, aunque en otra dimensión, si algo parecido ocurre con aquellas inscripciones que contienen el término ludaeus/ a como determinativos del nombre. Esto ocurre en varias inscripciones. La de Villamesías (Cáceres) completa un no infrecuente nombre latino Alucius Roscius con el término ludeus, monoptongación del correcto ludaeus. La otra es la inscripción de Adra, que corresponde quizá al siglo III, recoge también el nombre de (An)n ia Salo(mo)nula, en el que además del nombre Annia, que podría ser quizá una asimilación del bíblico Anna y del cognomen Salo(mo)nula, explicitando su carácter semita, aparece la pertinente indicación ludaea, resaltando con ello, presuntamente su raigambre judía. Esto nos lleva a la consideración de qué implicaba y qué es lo que podía implicar aquí el término ludaeus, al que inicialmente no le era ajeno el designar la "pertenencia al pueblo judío" con componente "geográfico" implícito aplicable no sólo a aquellos que vivian o habitaban en Palestina, sino también aquellos otros que vivían o procedian de otros lugares ${ }^{96}$.

No faltan casos en los que el término tiene un claro sentido geográfico; pero la utilización del vocablo asume también connotaciones religiosas que alcanzan incluso a los prosélitos, a los que se les aplica también dicho término; de modo que no puede deducirse automáticamente que el personaje en cuestión sea un emigrante originario de tierras palestinas. Para (An)nia Salo(mo)nula, que muere en Adra a la edad de un año, cuatro meses y un día, dicha suposición resultaría poco probable. El vocablo es utilizado como indicativo de ser un fiel de la religión judia o como término de pertenencia a la comunidad judía, como parecen ser los casos de la inscripción de Adra y de la de Villamesías.

Con ello nos vemos abocados a considerar brevemente cómo podia entenderse en líneas generales la pertenencia al pueblo judío. Decimos

96 LowE, M., "Who were the loudaioi?", Novum Testamentum. An International Quarterly for New Testament and Related Studies, n. ${ }^{\circ} 18,1976$, págs. 101-130; SoLIN, H., "Juden und Syrer...", op. cit., "Exkurs zu ludaeus», págs. 647-651. 
en líneas generales no sólo porque es un hecho que no se dispone de la pertinente información de cómo entendían los judíos asentados en Hispania su pertenencia al pueblo, al ethnos judío, sino porque autores como Filón de Alejandría o Flavio Josefo, que desarrollan en extensión sus opiniones al respecto, aunque coinciden en muchos aspectos, mantienen también discrepancias. El ethnos judío no responde a la noción de comunidad política organizada y establecida en un territorio concreto y definido. Se refiere a un ente, a un conjunto, en el que quedan englobados los judíos de todo el mundo, los residentes en Palestina y los de la diáspora. Ese ethnos se fundamenta sobre unos elementos comunes que abarcan y relacionan entre sí a todos sus miembros. En este sentido, Filón cree que todos los miembros que integraban el ethnos judío estaban unidos por un «parentesco común" $y$, además, de su pertenencia a una patria chica concreta, disfrutaban de una "ciudadanía única", la judía, de una ley idéntica, y de un Dios único venerado por todos los miembros del ethnos. En definitiva, que comúnmente se consideraba que el ethnos judío, la comunidad judía quedada establecida con relación a una sola ciudadanía, a una sola ley y a un solo Dios.

Pero, dejando de lado aquellas inscripciones que contienen indicación geográfica de procedencia de tierras hebreas y de aquellas otras en que la mención ludaeus/a remite al carácter religioso, a la consideración de miembro de la comunidad judía, parece que existían algunas comunidades judías que alcanzaron una relativa importancia, como Tarraco, llici, etc., si nos fiamos por la relativa mayor abundancia de testimonios de diversa índole de que disponemos. El número les daba fuerza y les ponía a resguardo de ser absorbidos por la comunidad no judía del entorno. Es cierto, $y$ es dato de experiencia constatable en otros lugares, que había una tupida red de relaciones, que conectaban a las comunidades más importantes entre sí y hasta a los centros judios más pequeños. Esto hacía que pequeñas comunidades, incluso aquellas que se encontraban en regiones más apartadas, desarrollasen un fuerte espíritu de cohesión cara al interior y una relativa reacción cara a las gentes foráneas. Pero no todos los testimonios dan a entender la existencia de comunidades judías de relativa entidad en la que algunos judíos pudieran quedar arropados. Algunos debieron de verse abocados a relacionarse en diversos grados culturales con los ambientes no judíos del entorno. Es posible, e indudablemente se trata de una consideración previa normal, que las comunidades no judias en las que los posibles judios aislados estuviesen inmersos ejerciesen sobre los mismos fuertes influencias y previsiones creando un ambiente cultural y espiritual más estandarizado y propiciando un relativo indiferentismo. 
Además de las menciones expresas a la procedencia y a las creencias judías, ¿qué otros elementos gráficos y ornamentales se encuentran en las inscripciones que permitan con suficiente fiabilidad, por una parte, conocer la pertenencia judía de la persona en cuestión y, por otra, constatar su participación en las creencias ancestrales judías. En este sentido, el registro en las inscripciones de expresiones como cum pace, in pace, amen, etc. ${ }^{97}$, es indicación consciente de participación en las creencias judías. Eran expresión de una esperanza mística, que se percibe ya en época judeo-helenística, en que el término griego eirene, y, posteriormente, en el latin pax, que traducía de forma bastante precisa el concepto místico del hebraico Shalom ${ }^{98}$ y que luego recogerán las inscripciones cristianas. Lo que ocurre es que las inscripciones hispanas que contienen las fórmulas indicadas parece que hay que situarlas en fechas muy avanzadas, aunque es cierto que diversos investigadores hacen varias propuestas que abarcan un amplio espectro cronológico, desde el siglo ॥ hasta el siglo $\mathrm{VI}^{99}$.

97 La inscripción bilingüe de Tarragona, recogida en nuestra nota 64 , y que cronológicamente se sitúa en el siglo iv, contiene la expresión (r(equies)/cit cum pac(e). El dedicante, originario de Cícico (Propóntide), era nieto de Rab. Latouves y archisinagogo de la comunidad judía de Tarragona.

De esta misma ciudad procede también otra inscripción, recogida y comentada por varios investigadores, CANTERA, F., “¿Nueva inscripción trilingüe tarraconense? ", Sefarad, n. ${ }^{\circ} 15,1955$, págs. 151 y ss.; Cantera, F. y Millás, J. M., "Inscripciones...", op. cit., n. ${ }^{\circ} 243$; Cantera, F., "España medieval: Arqueología", en R. D. Barnett (ed.), The Sephardi Heritage. Essais on the History and Contributions of the Jews of Spain and Portugal, I. Londres 1971, pág. 32; ALFOLOY, G., "Die römischen», op. cit., 1076: la traducción del texto hebreo reza así «la paz sea con Israel, con nosotros y con nuestros hijos". Debajo se encuentra pax fides y debajo de esos vocablos restos de letras griegas.

De Pallaresos, perteneciente al territorio de Tarragona, proviene una inscripción, que contiene la expresión im pace cum omne Israel. Amen, amen, amen. Sobre esta inscripción, ver MilLÁs, J. M., «Epigrafía hebraico-española», Sefarad, n. ${ }^{\circ}$ 5, 1945, págs. 290-291; CANTERA, F. y MILLÁs, J. M., "Las inscripciones...", op. cit., n. ${ }^{\circ} 290$; A. Ferrua en VIVES, J., "Inscripciones cristianas...», op. cit., $n .{ }^{\circ} 430$; ALFÖLDY, G., "Die römischen Inschriften...", op. cit., 1074: Hic est/ memoria bone re/cordationis. Isid/ora filia bene me/morii lonati et Ax/iaes. Pauset ani/ma eius in pace cu/m omne Israel. (am)en, amen, amen.

La inscripción trilingüe de Tortosa contiene las expresiones cum pace. amen. eiréne, eiréne. Sobre esta inscripción, ver FreY, J. B., "Corpus...», op. cit., n. ${ }^{\circ} 661$; A. Ferrua en VIVES, J., "Inscripciones cristianas...", op. cit., n. ${ }^{\circ} 428$; CANTERA, F., y MILLAS, J.M ., "Inscripciones...", op. cit., n. ${ }^{\circ} 198$.

${ }_{98}$ Ver, sobre este aspecto, STEIN, E., Die allegorische Exegese des Philo aus Alexandreia, 1929, pág. 51.Sobre este término en las inscripciones, ver DINKLER, E., "Shalom-Eirene-Pax: jüdische Sepulkralinschriften und ihr Verhältnis zum frühen Christetum", Rivista di Archeologia Cristiana, $n .{ }^{\circ} 50,1974$, págs. 121-144. Sobre la utilización del vocablo amen, ver también Solin, H., "Juden und Syrer...”, op. cit., págs. 701-702.

99 A la inscripción bilingüe de Tarragona, que recogemos en nuestra nota 64 , se le otorga una situación cronológica en el siglo iv, GARCiA IGLESIAS, L., “Los judíos...», op. cit., pág. 35 de la separata y doc. VI. VIVES, J. («Inscripcione s cristianas...", op. cit., pág. 60) considera hipotéticamente que la fórmula hic requiescit no es anterior al 450 . Caso de que una conclusión de 
Algunas de estas inscripciones, además de registrar nombres de procedencia judía, contienen también, por una parte, una serie de símbolos, menorah, shofar, etc., que son, obviamente, de clara raigambre judía y que, por tanto, evidencian una creencia judía; por otra, otros símbolos funerarios comunes a judíos y no judíos, como exponente de un ambiente cultural común y muy mezclado ${ }^{100}$. Por cierto que el hecho de que sean comunes a judíos y no judíos suscita la cuestión metodológica de hasta qué punto estos elementos simbólicos comunes son meramente decora-

este tipo fuese correcta, tendríamos que situar cronológicamente esta inscripción en el siglo $\mathrm{V}$. Por su parte SolıN, H., "Juden und Syrer...», op. cit., pág. 750, atendiendo a que G. Alföldy supone que la inscripción contiene la mención a los visigodos, piensa que la inscripción que consideramos no debería ser muy anterior a los finales del siglo $\mathrm{v}$.

La inscripción trilingüe de Tarragona recibe diversas propuestas cronológicas. BEINART, J., "¿Cuándo llegaron...», op. cit., págs. 119 y ss., sitúa esta inscripción entre los siglos I-III; CAN. TERA, F., «España medieval», en R. D. Barnett (ed.), “The Sephardi...», op. cit., piensa que podría colocarse entre el siglo III y el vi; García IGLESIAS, L., "Los judíos...", op. cit., pág. 173, por razones paleográficas considera que debería de situarse en época visigoda, anterior al 438

La inscripción de Pallaresos, Goodenough, E. R., Jewish Symbols in the Graeco-Roman period, II. Nueva York 1953, pág. 59, la sitúa entre los siglos I-III. CANTERA, F., "España medieval...", op. cit., pág. 32, propone para esta inscripción una datación en el siglo IV; CANTERA, F. y MiLLÁS, J. M., "Las inscripciones hebraicas...", op. cit., pág. 444. Solín, H., "Juden und Syrer...", op. cit., pág. 750, apoyado en la lectura proporcionada por $\mathrm{G}$. Altöldy, piensa, sin especificar más, que no es anterior al siglo IV. CANTERA, F. y MILLAS , J. M., "Las inscripciones hebraicas...», op. cit., pág. 444 y GARCíA IGLESIAS, L., "Los judíos...", op. cit., pág. 13 de la separata, la consideran como correspondiente al siglo vill.

A la inscripción de Tortosa, Beinart, J., "iCuándo llegaron...", op. cit., págs. 25 y ss., 10 mismo que ocurre con la inscripción anterior, la sitúa en fecha imprecisa, pero temprana. CANTERA, F., “España medieval...”, op. cit., pág. 33, propone que, entre los siglos $\|$ al v pudiera pertenecer a una fecha anterior al 438. Motivos de indole formal llevan a CANTERA, F. y MILLÁS, J. M., «inscripciones... ", op. cit., 198, a proponer para esta inscripción una posible pertenencia cronológica al siglo vi; hipótesis que es la que también defiende L. García Iglesias.

100 De Mártola procede una inscripción fragmentada en tres partes:.../(vi)xit ann(os)/ (...re)cessit i(n/pa)ce die quar(tas N)onas Octo/(bre)s era DXX, ver ALvES DIAS, M. M., FE, 21, $1987, \mathrm{n}^{\circ}{ }^{\circ}$ 93, que es la lectura que seguimos. El fragmento correspondiente a la parte central inferior contiene el símbolo inciso de un candelabro, de innegable vinculación judía. Lo cierto es que, en contraste con el resto de inscripciones hispanas que recogen esos símbolos, pero que, a su vez, no contienen indicación expresa de la fecha de la pieza, la inscripción de Mértola registra la fecha de 4 de octubre del 482.

Con relación al resto de las inscripciones que documentan elementos simbólicos resulta oportuno aludir a una serie de inscripciones, algunas de las cuales ya han sido mencionadas en relación a alguna otra característica judía. Entre éstas se encuentra la ya aludida inscripción trilingüe tarraconense, incisa en un monumento, que se ha interpretado como una pileta de abluciones o como un sarcófago infantil. En esta inscripción, además del menorab y del shofar, se recogen otros símbolos funerarios. Por su parte, la inscripción de Pallaresos ofrece doble menorab. La inscripción trilingüe de Tortosa, además del menorab, contiene dos estrellas de David. De Orinuela parece proceder una estela decorada que lleva grabado el arranque de menorab y de los dos pavos reales. Desde el punto de vista cronológico, se piensa, sin datos decisivos, que esta estela pudiera situarse cronológicamente a finales del siglo vi, o en el siglo VII. Sobre esta pieza ver VILAR, J. B., Orihuela en el mundo antiguo. Orihuela-Murcia 1975, págs. $172-173$. 
tivos y expresión del ambiente cultural en el que estaban inmersos, o hasta qué otro han sido asumidos con su carga simbólica dentro del sistema de símbolos judíos.

Pero, al margen de varias inscripciones que contienen algunos antropónimos de clara raigambre hebrea y que parecen remontarse a época romana altoimperial, las otras, que contienen nombres hebreos, fórmulas y símbolos inequívocamente judíos, responden a un factor común: todas ellas parecen corresponder a época avanzada. Aquellas otras que se sitúan en época romana anterior a las invasiones, y que, por los nombres orientales que contienen, algunos investigadores las consideran como posiblemente pertenecientes a judíos, ciertamente se encuentran inmersas en un marco cultural que sugiere una dimensión étnico-religiosa judía. Para captar dicha dimensión en el conjunto de inscripciones funerarias que, en razón a los antropónimos que contienen, se consideran como pertenecientes, quizá, a judíos, se ha utilizado como criterio clasificatorio si dichas inscripciones están acogidas o no a la fórmula D. M. (S.). Asumiendo como válido este criterio, algunos investigadores suponen que aquellos personajes con antropónimos orientales, que en las inscripciones funerarias no se acogen a la fórmula $D$. M. (S.), lo hacen así en razón de su condición de judíos, a la que subyacería una connotación de carácter religioso ${ }^{101}$. En el caso de que este criterio fuese indiscutiblemente fiable, habria que concluir que Barathes de la inscripción procedente de Peñaflor, Baritto de la Toscana, Bailén, Sempornia Marta de Mérida, Fabia Maria de Tarragona, etc., no correspondían a judíos. Quizá la utilización de este criterio tenga mayor fiabilidad cuando la inscripción en cuestión proceda de localidades que sabemos que contaban o que luego se constatará que contaban con importantes comunidades judías, pero ya no resulta tan seguro con inscripciones procedentes de lugares en los que no parece constatarse comunidades judías, o porque no existieron realmente o porque tal vez su importancia numérica era muy pequeña. En cualquier caso, la aparición o no de la fórmula D. M. (S.) no puede tomarse como criterio de aplicación mecánica para considerar o no como judíos a las personas implicadas en esas inscripciones. No lo ha sido, tal y como se ha indicado 102 en el caso de algunas inscripciones indiscutiblemente judías que mantienen esa fórmula y tampoco lo será en algunas otras cristianas que

to1 Garcia IgLesias, L., “Los judíos...”, op. cit., págs. 61 y 64, con relación a inscripciones que recogen nombres orientales, y que están acogidas a la fórmula D.M.(S.), piensa que es muy difícil que pueda tratarse de inscripciones pertenecientes a judios.

102 Solin, H., “Gli Ebrei d'Africa: una nota», en Atti dell'VIII Convegno di Studio su l'Africa romana, t. I. Sassari 1991, pág. 615, nota 1, especifica cla dedica agli Dei Mani D.M.(S.) non è sufficiente per respingere il carattere "giudeo" vero e proprio dell'iscrizione". 
también la mantienen. Indudablemente que la fórmula había reflejado y refleja antiguas creencias paganas ${ }^{103}$; pero en los casos considerados pudiera tratarse ciertamente ya de un elemento desvirtuado con el que se estaba señalando meramente el carácter sepulcral del monumento. La plasmación de dicha fórmula estaría propiciada por el hecho de que no pocas comunidades, tanto judías como cristianas, se encontraban más o menos influenciadas por las tradiciones culturales, sobre todo por las costumbres funerarias, que se dejan transformar más lentamente, de las gentes del entorno. Y esta suposición alcanzaría mayor solidez para aquellas inscripciones correspondientes a posibles y aislados judíos inmersos en comunidades paganas que estarían ejerciendo sobre los mismos fuertes influencias y presiones, creando un ambiente cultural más mezclado y ambiguo. Indiscutiblemente, en este tipo de consideraciones y valoraciones siempre tiene oportuna acogida las preguntas metodológicas acerca del valor real que pudieran asumir en contextos judíos -como sería hipotéticamente el de las inscripciones consideradas- la utilización de las fórmulas aludidas, de símbolos y de objetos paganos. Pero la respuesta no es simple, ya que resulta difícil determinar si esas fórmulas, figuras de origen pagano, etc., constituyen unos elementos decorativos, o son la expresión de la annuencia o relación con las gentes y culturas paganas que les rodean, o bien, por el contrario, responden a algo más. Qué duda cabe que el registro y la aparición de la fórmula D. M. (S.) puede resultar un indicio importante, pero en modo alguno constituye un exponente indiscutible de un inequívoco posicionamiento religioso y mucho menos aun de una postura religiosa determinada. $Y$ a este respecto hay que tener presente que, incluso en la utilización de elementos de clara raigambre judaica, cuando se pretenden profundizar en algo más que la simple constatación de que son fórmulas y objetos propiamente judaicos, la incertidumbre acerca de lo que en concreto se pretende evocar, aumenta de un modo apreciable ${ }^{104}$.

103 BECKER, F., Die heidnische Weiheformel D.M.(Diis Manibus sc. Sacrum) auf altchristlichen Grabsteinen. Gera 1881, págs. 1, 8-10 y 65-67; SCHWARzLOSE, W., De titulis sepulcralibus Latinis quaestionum capita quattuor. Halis Saxonum 1913, págs. 16-18.

104 Momigliano, A., "Problemi di metodo nella interpretazione dei simboli giudeo-ellenistici", recogido en Secondo contributo alla storia degli studi classici e del mondo antico, t. II. Roma 1980 , al valorar la obra de E. R. Goodenough, se hace diversas preguntas acerca de si las fórmulas y figuras paganas utilizadas por los judios son meramente decorativos, o han sido asumidos, dentro del sistema de simbolos judios, con sus pertinentes significaciones. Concluye que carecemos de criterios sólidos, pues no se cuenta con la necesaria información literaria, que explique de forma pertinente la utilización de esos objetos y símbolos. Y esto incluso ocurre cuando se tiene a disposición información literaria sobre algunos de esos objetos genuinamente judíos. Y dice al respecto: "De hecho nadie puede saber si esa compleja alegoría del candelabro que presenta Filón y que también menciona Flavio Jesefo (IV, págs. 82-88) estaba presente en la mente de aquel judío que ponía el candelabro sobre la tumba de una persona querida". Y a 
Se ha dicho que las inscripciones son "la voz del monumento" ${ }^{105}$. No vemos que en las inscripciones propuestas, a modo de hipótesis, como correspondientes a judíos no se puedan constatar ni tampoco filtrar elementos que hagan pensar sin discusión en esa personalidad tan peculiar que asumen los judios y en esa profunda creencia religiosa tan característica del pueblo judío. No se encuentran en ellas datos que hagan percibir con diversas variantes y formulaciones, huellas de creencias $y$ esperanzas en ultratumba con las que se encuentran muy relacionados otros testimonios judíos extrapeninsulares ${ }^{106}$.

La erección de inscripciones funerarias no es casual, sino que responde a una intención consciente de aquellos que la erigen en favor del difunto y con destino al público y al lector. Con las inscripciones funerarias se pretende ocupar un sitio en el recuerdo de la comunidad viviente. Pero la consecución de este objetivo y la atención que las inscripciones suscitaban dentro de la comunidad viviente dependía, en gran medida, del éxito de las inscripciones en transmitir el mensaje que la comunidad sensible al mismo, sobre todo si era de específico contenido religioso, esperaba recibir, y en la adecuación del contenido del documento con la realidad. Para hacerse entender en el terreno ideológico, los epitafios deben hacer uso dentro del texto epigráfico de determinados elementos ideológicos, complementados por otros figurativos, y eso se aprecia en la mayoria de las inscripciones atribuidas a los judíos. Estas inscripciones nos remiten a un mundo de costumbres ancestrales generales, en el que se desarrolla la práctica de recordar a los muertos mediante epígrafes de esas características, erradicadas después lentamente por la hebraización. Pero, mientras ese proceso aguardaba para completarse, por influencia, y quizá también por inercia, las inscripciones atribuidas a probables judíos ofrecen una tozuda persistencia de costumbres funerarias paganas, como la creencia en los Dii Manes, con frecuente expresión textual, la idea de la tumba como receptáculo del alma, con el H.S. E., y el sentido de la fórmula S. T. T. .L., reiteradamente utilizada, que en inscripciones de clara raigambre hebrea, aunque mucho más tardias que las romanas que estamos considerando, se verá sustituida con expresiones como cum pace, amén in pace cum omne Israel, amén, amén, amén.

este respecto concluye que "en la época del "judaísmo normativo" (siglo x) Sa'adya Galón podía dar diez interpretaciones distintas al sonido de la trompeta" (IV, pág. 194).

105 JeRPhanion, G. de, "Que doit être un manuel d'épigraphie chrétienne?», en La voix des monuments. Notes et études d'archéologie chrétienne. París-Bruselas 1930, pág. 21, por lo que se refiere a las inscripciones, dice que éstas son ala voz del monumento".

106 Ver al respecto Leipoldt, J. y GRUNDMANn, W., El mundo del nuevo Testamento, $t$. I. Madrid 1973, pág. 322. 